\title{
REVIEW
}

\section{The role of vitamin $D$ in breast cancer risk and progression}

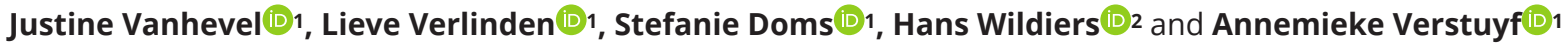 \\ ${ }^{1}$ Clinical and Experimental Endocrinology, Department of Chronic Diseases and Metabolism (CHROMETA), KU Leuven, Leuven, Belgium \\ zUZ Leuven, General Medical Oncology and Multidisciplinary Breast Center, Leuven, Belgium
}

Correspondence should be addressed to A Verstuyf: mieke.verstuyf@kuleuven.be

\begin{abstract}
The active form of vitamin $D_{3}, 1,25$-dihydroxyvitamin $D_{3}\left(1,25(\mathrm{OH})_{2} \mathrm{D}_{3}\right)$, is primarily known as a key regulator of calcium and phosphate homeostasis. It exerts its biological functions by binding to the vitamin $D$ receptor (VDR), a transcription factor that regulates gene expression in vitamin D-target tissues such as intestine, kidney and bone. Yet, the VDR is expressed in many additional normal and cancerous tissues, where it moderates the antiproliferative, prodifferentiating and immune-modulating effects of $1,25(\mathrm{OH})_{2} \mathrm{D}_{3}$. Interestingly, several epidemiological studies show that low levels of $25(\mathrm{OH}) \mathrm{D}$, a biological marker for $1,25(\mathrm{OH})_{2} \mathrm{D}_{3}$ status, are associated with an increased risk of breast cancer (BC) development. Mendelian randomization studies, however, did not find any relationship between single-nucleotide polymorphisms in genes associated with lower serum $25(\mathrm{OH}) \mathrm{D}$ and $\mathrm{BC}$ risk. Nevertheless, multiple in vitro and in vivo preclinical studies illustrate that $1,25(\mathrm{OH})_{2} \mathrm{D}_{3}$ or its less calcaemic structural analogues influence diverse cellular processes in $\mathrm{BC}$ such as proliferation, differentiation, apoptosis, autophagy and the epithelialmesenchymal transition. Recent insights also demonstrate that $1,25(\mathrm{OH})_{2} \mathrm{D}_{3}$ treatment impacts on cell metabolism and on the cancer stem cell population. The presence of VDR in the majority of $B C s$, together with the various anti-tumoural effects of $1,25(\mathrm{OH})_{2} \mathrm{D}_{3}$, has supported the evaluation of the effects of vitamin $D_{3}$ supplementation on $B C$ development. However, most randomized controlled clinical trials do not demonstrate a clear decrease in $B C$ incidence with vitamin $D_{3}$ supplementation. However, $1,25(\mathrm{OH})_{2} \mathrm{D}_{3}$ or its analogues seem biologically more active and may have more potential anticancer activity in $\mathrm{BC}$ upon combination with existing cancer therapies.
\end{abstract}

\author{
Key Words \\ - vitamin D \\ - breast cancer \\ - vitamin D receptor \\ - anti-neoplastic effects \\ - epidemiological studies
}

\section{Introduction}

Vitamin $\mathrm{D}_{3}$ (cholecalciferol), a natural form of vitamin $\mathrm{D}$, can be obtained from dietary sources (such as fatty fish) but is also generated in the human skin under influence of sunlight (UVB radiation, 290-320 nm) from its precursor, 7-dehydrocholesterol (Leyssens et al. 2013, Christakos et al. 2016, 2019, Jeon \& Shin 2018). Since exposure to sunlight is a major trigger for vitamin $D_{3}$ synthesis in the skin, alterations in sunlight exposure based on season and latitude will influence the ability to synthesise vitamin $D_{3}$ (Spiro \& Buttriss 2014). The biologically active form of vitamin $D_{3}, 1 \alpha, 25$ dihydroxyvitamin $\mathrm{D}_{3}\left(1,25(\mathrm{OH})_{2} \mathrm{D}_{3}\right)$, is generated by two hydroxylation steps. First, vitamin $\mathrm{D}_{3}$ is hydroxylated at carbon 25 by CYP2R1/CYP27A1 (cytochrome P450 enzymes) in the liver to generate 25 -hydroxyvitamin $\mathrm{D}_{3}$ $\left(25(\mathrm{OH}) \mathrm{D}_{3}\right)$, a reliable serum marker for vitamin D status. 
Next, in the kidney, CYP27B1 hydroxylates $25(\mathrm{OH}) \mathrm{D}_{3}$ at carbon 1 to generate $1,25(\mathrm{OH})_{2} \mathrm{D}_{3}$. Another important cytochrome P450 enzyme in the kidney is CYP24A1. This enzyme regulates the circulating levels of $1,25(\mathrm{OH})_{2} \mathrm{D}_{3}$ by hydroxylating carbon 24 not only in $1,25(\mathrm{OH})_{2} \mathrm{D}_{3}$ but also in $25(\mathrm{OH}) \mathrm{D}_{3}$, thereby decreasing the pool of $25(\mathrm{OH}) \mathrm{D}_{3}$ available for carbon 1 hydroxylation. These 24-hydroxylated products are excreted via urine or faeces (Christakos et al. 2016). 1,25(OH) ${ }_{2} \mathrm{D}_{3}$ exerts its functions after binding to the vitamin $\mathrm{D}$ receptor (VDR), which subsequently heterodimerizes with the retinoid $\mathrm{X}$ receptor (RXR). Both VDR and RXR are members of the nuclear receptor superfamily. There are three subtypes of RXR $(-\alpha,-\beta$ and $-\gamma)$, of which RXR $\alpha$ is the most important isoform for VDR activity (Peehl \& Feldman 2004). Binding of VDR to RXR is reported to induce a non-permissive heterodimer complex that cannot be activated by the RXR ligand, 9-cis retinoic acid (RA) (Sanchez-Martinez et al. 2006). Moreover, in vitro studies have shown that $1,25(\mathrm{OH})_{2} \mathrm{D}_{3}$ enhanced the formation of RXR-VDR heterodimer whereas 9-cis RA reduced their affinity by inducing RXR-RXR homodimerization. Also, the availability of both receptors will influence their responsiveness to the ligands (Lemon \& Freedman 1996). However, in vitro studies in MCF7 cells have shown that both 9-cis RA and $1,25(\mathrm{OH})_{2} \mathrm{D}_{3}$ can induce CYP24A1 gene activation suggesting that the VDR-RXR heterodimer is a conditionally permissive heterodimer rather than a nonpermissive heterodimer (Sanchez-Martinez et al. 2006). After binding of VDR to RXR, this complex will migrate to the nucleus and bind to vitamin $\mathrm{D}$ response elements (VDREs) in regulatory regions of target genes to regulate gene transcription by recruiting co-activators (p160, DRIP205) and by losing co-repressors (NCoR, SMRT) (Leyssens et al. 2013, Christakos et al. 2016, 2019, Jeon \& Shin 2018).

The main function of $1,25(\mathrm{OH})_{2} \mathrm{D}_{3}$ is to maintain calcium and phosphate homeostasis in the body. Yet, the VDR is not only expressed in intestine, kidney and bone tissue, but also in many other, including cancerous, tissues. Both in vitro and in vivo preclinical studies have illustrated that $1,25(\mathrm{OH})_{2} \mathrm{D}_{3}$ modulates variable signalling pathways involved in cell proliferation, apoptosis, differentiation, inflammation, invasion and angiogenesis (Welsh 2018) (reviewed in Christakos et al. 2016).

In the 1980s, the group of Garland was the first to describe a possible association between sunlight exposure and breast cancer (BC) risk (Garland et al. 1990, 2006). Thereafter, different epidemiological and preclinical studies have investigated a possible correlation between
25(OH)D serum concentration and the development and progression of BC. However, these studies have shown conflicting results (Hossain et al. 2019).

With 2.3 million diagnoses each year, BC is the most frequently diagnosed cancer in women and the leading cause of cancer-related mortality worldwide (Mattiuzzi \& Lippi 2019, Sung et al. 2021). Breast tumours arise from the epithelial cells of the breast located in the milk ducts or lobules (milk-producing glands). Clinically, BC can be subdivided into different subtypes based on the expression of oestrogen receptor (ER), progesterone receptor (PR) and amplification of the human EGF receptor 2 (HER2). These markers allow histological classification of BC tumours into hormone receptor-positive tumours (luminal A and B), HER2 amplified tumours and triple-negative breast cancer (TNBC) tumours (Mueller et al. 2018). The luminal subtype (A-B) is the most common subtype of $\mathrm{BC}$ accounting for $60-70 \%$ of all $\mathrm{BC}$ diagnoses. Luminal A BCs have a better prognosis than luminal B BC as they express lower levels of Ki67-positive cells. TNBC is a subtype of basal-like $\mathrm{BC}$ and has the worst prognosis of all BC subtypes. Basal-like BC is characterized by the expression of keratin 5, 14 and 17 and occurs mainly in young premenopausal women under the age of 40 , accounting for $15-20 \%$ of BC diagnoses (Yin et al. 2020, Johnson et al. 2021).

In this review, we summarize the role of vitamin D in processes such as proliferation, apoptosis, inflammation and autophagy in various in vitro and in vivo $\mathrm{BC}$ models. Moreover, we extensively focus on the more recent research that illustrates the effect of $1,25(\mathrm{OH})_{2} \mathrm{D}_{3}$ on tumour metabolism, metastasis, epithelial-mesenchymal transition (EMT) and cancer stem cells, which represent novel pathways that could be targeted to hamper BC progression. Finally, we discuss potential strategies to overcome the hypercalcaemic side effects, which are associated with the supraphysiological concentrations of $1,25(\mathrm{OH})_{2} \mathrm{D}_{3}$ required to obtain its anti-neoplastic activity. Indeed, $1,25(\mathrm{OH})_{2} \mathrm{D}_{3}$-derived synthetic analogues have been developed with the rationale to design analogues with an optimal ratio of anti-neoplastic vs calcaemic effects (Leyssens et al. 2013, 2014, Duffy et al. 2017). These analogues are currently being tested in combination with selective pathway inhibitors in experimental models to block tumour growth and progression. An overview of the described cell lines with their expression of VDR, CYP24A1 and CYP27B1 and the pathways regulated by $1,25(\mathrm{OH})_{2} \mathrm{D}_{3}$ are presented in Table 1. We used the keywords 'vitamin $\mathrm{D}$ and $\mathrm{BC}$ ' to search for papers in the MEDLINE database between 2015 and 2020. 


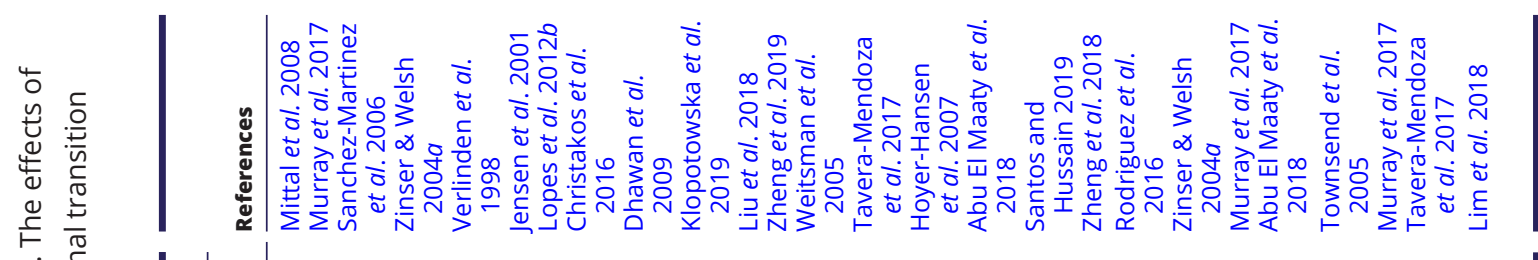

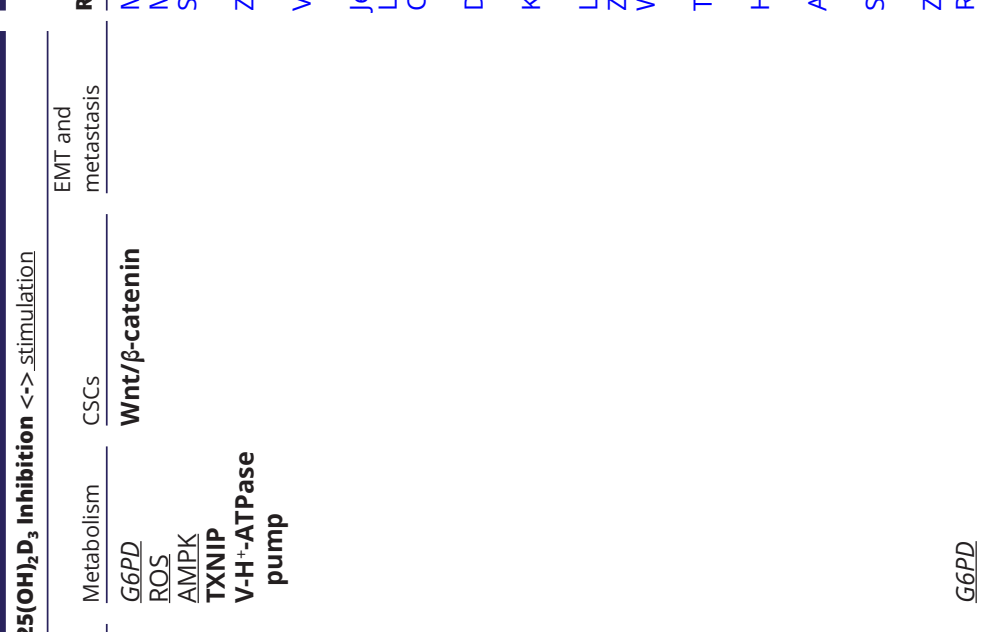

을

ह்

वे 리

吾 焉

完

उ.

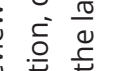

|

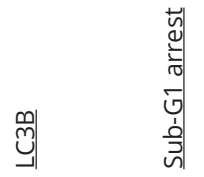

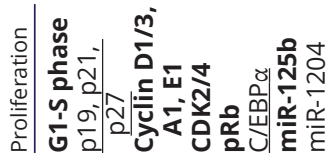

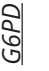

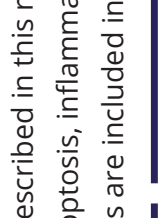

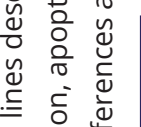

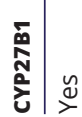

辛|

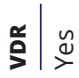

产帘

बै

旁

竞

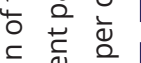

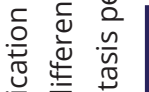

宸|

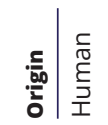

$\stackrel{\varrho}{>}$

$\stackrel{\varrho}{\nu}$

$\stackrel{y}{\stackrel{y}{\nu}} \quad \stackrel{0}{\nu}$

$\stackrel{\check{\nu}}{\nu}$

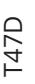

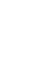

剀

U $\mathrm{O}^{m} \frac{\varepsilon}{0}$

- 鱼完

을 은

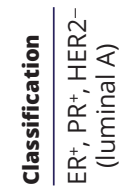



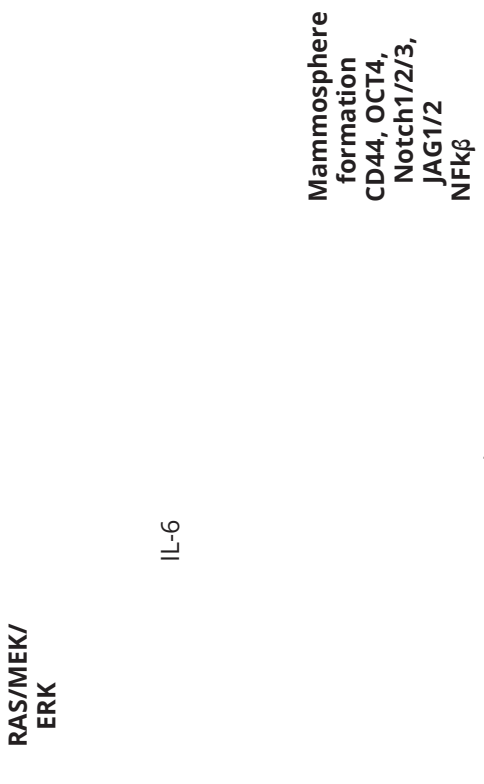

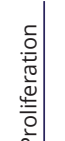

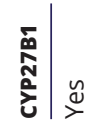




\section{VDR expression in human breast cancer cells}

The VDR is expressed in different cell types of the mammary gland, including the lobular and ductal epithelial cells, where it plays an important role in mammary gland development during puberty, lactation and pregnancy, periods of maximal tissue growth and remodelling (Zinser $\&$ Welsh 2004a, Huss etal. 2019). During the pubertal period in mice, VDR expression was highest in differentiated cells in the terminal end buds, while its expression was low in the proliferative zones of the mammary gland (Zinser $e t a l$. 2002). In $V d r$ knock-out (KO) mice, ductal morphogenesis and branching in the mammary glands were accelerated compared to WT mice during the pubertal period. Furthermore, in transgenic MMTV-neu mice, $V d r$ ablation induced weight loss, atrophy of the mammary fat pad, oestrogen deficiency and reduced survival after 12 months of age (Zinser \& Welsh 2004b).

Adipocytes also play an important role in mammary gland development, as $V d r$ deletion in adipose tissue enhanced the density of the mammary epithelium during hormonally regulated expansion of the mammary gland (Matthews et al. 2016). As adipose tissue is a storage depot for vitamin D metabolites, VDR signalling between adipocytes and epithelial cells plays an important role not only in normal mammary gland development but also in carcinogenesis (Welsh 2017). The VDR is also expressed in cancer-associated fibroblasts (CAFs), in which stimulation with $1,25(\mathrm{OH})_{2} \mathrm{D}_{3}$ downregulated different genes important during cell proliferation (e.g. Neuregulin NRG1) (Campos et al. 2013).

In human BC tissue, VDR expression has been reported to be inversely correlated with $\mathrm{BC}$ aggressiveness. In benign breast lesions, the VDR was significantly more expressed than in breast carcinoma lesions (in situ and invasive) (Lopes et al. 2010). Furthermore, VDR expression was higher in luminal A BC than in TNBC, the most aggressive BC subtype (Welsh 2017, Huss et al. 2019). Different groups demonstrated that VDR expression in BC tissue diminished during tumour progression, rendering them less sensitive to vitamin $\mathrm{D}_{3}$ (Lopes et al. 2010, Welsh 2017). Indeed, BC cell lines with low or no VDR expression were least sensitive to $1,25(\mathrm{OH})_{2} \mathrm{D}_{3}$ or its analogues (Murray et al. 2017).

Moreover, different groups investigated if VDR expression could be used as a potential biomarker for cancer progression and survival (Al-Azhri et al. 2017, Heublein et al. 2017, Murray et al. 2017, Huss et al. 2019, $\mathrm{Xu}$ et al. 2020). Recently, higher total VDR expression in $\mathrm{BC}$ lesions (both in nucleus and cytoplasm) was associated with tumour characteristics such as lower grade, smaller 
size, ER/PR positivity, lower Ki67 expression and with a lower risk of BC mortality (Al-Azhri et al. 2017, Huss et al. 2019). Further analysis distinguishing between BRCA1mutated $\mathrm{BC}$ and sporadic $\mathrm{BCs}$ showed significantly higher VDR expression in BRCA1-mutated BCs, which is associated with prolonged overall survival (OS) (Heublein et al. 2017).

A recent meta-analysis containing seven studies reported no correlation between VDR expression and BC OS and disease-free survival (DFS). However, when subgroup analyses based on staining location were performed, high total VDR expression in both nucleus and cytoplasm was correlated with better BC OS. Moreover, when cut-off values for immunoreactive score (IRS) other than IRS $>5$ or IRS $>25$ were used, high VDR expression was correlated with better BC OS (Xu et al. 2020). IRS is a scoring system used for quantitative evaluation of immunohistochemical stainings and is based on the multiplication of the number of positive cells ( $0-4)$ and the staining intensity (0-3), resulting in a score between 0 and 12 (Fedchenko \& Reifenrath 2014). Murray et al. (2017) did not confirm the association between $V D R$ expression and BC DFS as a whole, although DFS was positively correlated with $V D R$ expression in luminal A BC patients, whereas no association was observed with basal-like, HER2 ${ }^{+}$or luminal B BC subtypes. Overall, these findings suggest that VDR expression levels could potentially be used as a biomarker for tumour progression.

Analysis of CYP24A1 and CYP27B1 expression in human $\mathrm{BC}$ tissue showed that during de-differentiation and $\mathrm{BC}$ progression, vitamin $\mathrm{D}$ metabolism and therefore VDR signalling is deregulated (reviewed in Welsh 2017). In most analyses, CYP27B1 expression levels decreased, whereas those of CYP24A1 were increased in more invasive breast carcinomas, suggesting that cancer cells can evade the anti-cancer effects of $1,25(\mathrm{OH})_{2} \mathrm{D}_{3}$ by decreasing its local production and increasing its local degradation (Lopes et al. 2010, Zhalehjoo et al. 2017). As a result, CYP24A1 is described as an oncogene in BC tissue (Albertson et al. 2000). Next to its expression in breast epithelial tissue, CYP27B1 is also expressed in breast adipose tissue. Breast adipocytes can activate local $25(\mathrm{OH}) \mathrm{D}_{3}$ into $1,25(\mathrm{OH})_{2} \mathrm{D}_{3}$ and induce paracrine effects on surrounding tissues (Welsh 2017). In CAFs, transcriptional induction of CYP24A1 by $1,25(\mathrm{OH})_{2} \mathrm{D}_{3}$ is more pronounced than in normal associated fibroblasts, suggesting a faster clearance in the tumour microenvironment (Campos et al. 2013).

However, a more recent study showed that CYP24A1 mRNA levels were lower in breast tumour tissue and inversely correlated with OS (Cai et al. 2019).

\section{Preclinical anti-neoplastic effects of $1,25(\mathrm{OH})_{2} \mathrm{D}_{3}$ on breast cancer}

\section{Effects of $1,25(\mathrm{OH})_{2} D_{3}$ on cell proliferation}

For many years, $1,25(\mathrm{OH})_{2} \mathrm{D}_{3}$ has been recognized to hamper the transition of $\mathrm{BC}$ cells from G0/G1 to $\mathrm{S}$ phase of the cell cycle. $1,25(\mathrm{OH})_{2} \mathrm{D}_{3}$ mediates these antiproliferative effects through VDR binding, since VDR $\mathrm{KO}$ cells are not growth inhibited by $1,25(\mathrm{OH})_{2} \mathrm{D}_{3}$ (LaPorta \& Welsh 2014, Zheng et al. 2017). 1,25(OH) $)_{2} \mathrm{D}_{3}$-mediated growth reduction is accompanied by an increased expression of cyclin-dependent kinase inhibitors (CDKIs) such as CDKN2D (p19), CDKN1A (p21) and CDKN1B (p27) and downregulation of cyclins (cyclin D1/3, cyclin A1 and cyclin E1) and CDKs (CDK2/4) (Verlinden et al. 1998, Jensen et al. 2001, Lopes et al. 2012b) (Fig. 1). In addition, upregulation of CDKI expression levels by $1,25(\mathrm{OH})_{2} \mathrm{D}_{3}$ decreases the activity of CDKs such as CDK4/6 and results in a reduced phosphorylation of retinoblastoma $(\mathrm{Rb})$, a tumour suppressor protein with a crucial role in the regulation of cell cycle progression. Consequently, $\mathrm{Rb}$ remains complexed to the $\mathrm{E} 2 \mathrm{~F}$ transcription factors (TFs) and transcription of E2F-regulated cell cycle genes such as CDK2 decreases (Christakos et al. 2016) (Fig. 1). Furthermore, in $\mathrm{ER}^{+} \mathrm{MCF} 7$ cells, the induction of $\mathrm{C} / \mathrm{EBP} \alpha$ expression and subsequent elevation of $V D R$ transcript levels also contributed to the antiproliferative effects of $1,25(\mathrm{OH})_{2} \mathrm{D}_{3}$ (Dhawan et al. 2009). In addition, $1,25(\mathrm{OH})_{2} \mathrm{D}_{3}$ affects expression of miRNAs, short

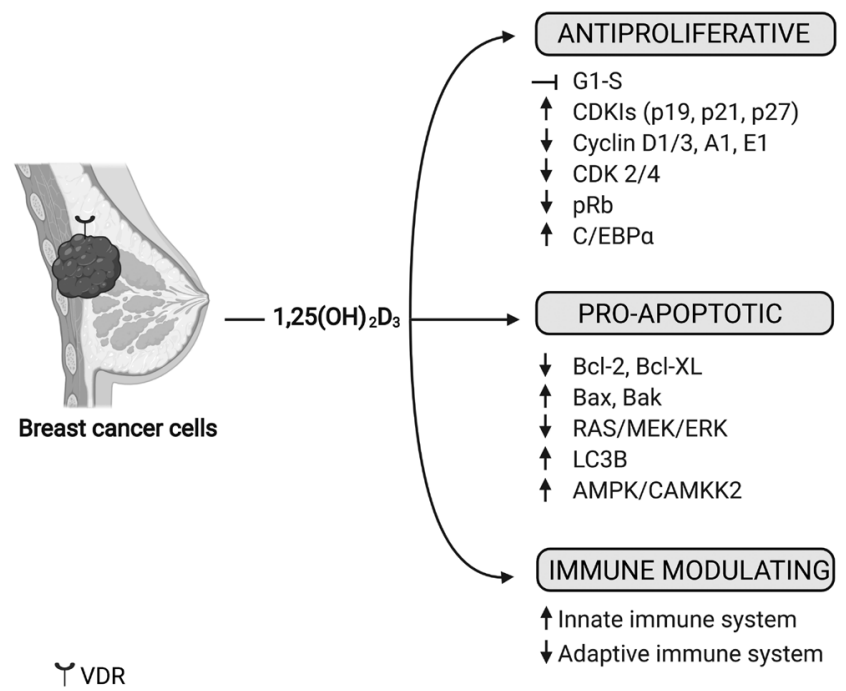

Figure 1

Overview of $1,25(\mathrm{OH})_{2} \mathrm{D}_{3}$-induced anti-neoplastic effects in pathways involved in the regulation of cell proliferation, apoptosis and inflammation in breast cancer cells. Created with BioRender.com. 
non-coding RNAs that regulate gene expression negatively at the post-transcriptional level. Treatment with $1,25(\mathrm{OH})_{2} \mathrm{D}_{3}$ or a vitamin $\mathrm{D}_{3}$ analogue (1,24-dihydroxyvitamin $\mathrm{D}_{3}$ (tacalcitol)) decreased the expression of miR-125b. As a consequence, the pro-apoptotic protein BAK1, encoded by the target gene of miR-125b, was increased after treatment with 1,25(OH) ${ }_{2} \mathrm{D}_{3}$ and tacalcitol (Klopotowska et al. 2019). Liu et al. illustrated that increased expression of miR1204 promoted proliferation, EMT and invasion of BC cells both in vitro and in vivo. Mechanistic studies showed that miR-1204 inhibited $V D R$ expression directly by targeting its 3' UTR and this VDR suppression contributed to the oncogenic activity of miR-1204. Indeed, silencing of $m i R-1204$ resulted in elevated VDR expression levels and reduced proliferation and invasiveness of BC cells (Liu et al. 2018).

$1,25(\mathrm{OH})_{2} \mathrm{D}_{3}$ has also clear in vivo antiproliferative effects as demonstrated in different (transgenic) mouse models (Welsh 2018). Recently, Rossdeutscher et al. (2015) demonstrated the growth-inhibitory effects of $1,25(\mathrm{OH})_{2} \mathrm{D}_{3}$ in an MMTV-PyMT model. Mice were subcutaneously implanted with a minipump, delivering continuous doses of $25(\mathrm{OH}) \mathrm{D}_{3}$ or $1,25(\mathrm{OH})_{2} \mathrm{D}_{3}$. Both treatments significantly decreased cell proliferation (Ki67, ErbB2, cyclin D1) and tumour growth. Interestingly, continuous supplementation with $25(\mathrm{OH}) \mathrm{D}_{3}$ increased local $1,25(\mathrm{OH})_{2} \mathrm{D}_{3}$ levels in tumour tissues without causing hypercalcaemia, whereas $1,25(\mathrm{OH})_{2} \mathrm{D}_{3}$ perfusion did induce hypercalcaemia (Rossdeutscher et al. 2015). In contrast, in a xenograft mouse model, derived from highly proliferative tumour tissues, intra-tumoural administration of $1,25(\mathrm{OH})_{2} \mathrm{D}_{3}$ was unable to decrease $\mathrm{BC}$ cell proliferation (BrdU incorporation, Ki67, CDKN1A, CDKN1B) or apoptosis (Bcl-2 expression) (Fonseca-Filho et al. 2017). Next to $1,25(\mathrm{OH})_{2} \mathrm{D}_{3}$, also its metabolites such as $24 \mathrm{R}, 25$ dihydroxyvitamin $\mathrm{D}_{3}\left(24 \mathrm{R}, 25(\mathrm{OH})_{2} \mathrm{D}_{3}\right)$ regulate $\mathrm{BC}$ cells in vitro and in vivo. $24 \mathrm{R}, 25(\mathrm{OH})_{2} \mathrm{D}_{3}$ stimulated $\mathrm{DNA}$ synthesis in ER+ MCF7 and T47D cells, acting through a caveolaeassociated phospholipase D-dependent mechanism via cross-talk with ERs. However, in vivo analysis of an MCF7 xenograft model showed that treatment with $24 \mathrm{R}, 25(\mathrm{OH})_{2} \mathrm{D}_{3}$ reduced tumour burden and increased animal survival by reducing markers of invasion and metastasis (Snail1, CXCR4/CXCL12) (Verma et al. 2019).

\section{Effects of $1,25(\mathrm{OH})_{2} \mathrm{D}_{3}$ on apoptosis and autophagy}

$1,25(\mathrm{OH})_{2} \mathrm{D}_{3}$ regulates different apoptotic pathways in a $\mathrm{BC}$ cell type-dependent manner. In general, $1,25(\mathrm{OH})_{2} \mathrm{D}_{3}$ decreases the expression of anti-apoptotic factors (Bcl-2,
Bcl-XL) and/or increases the pro-apoptotic equivalents (Bax, Bak), which direct cells towards cell death rather than to cell survival (Vanoirbeek et al. 2011). In addition, $1,25(\mathrm{OH})_{2} \mathrm{D}_{3}$ targets the RAS/MEK/ERK signalling pathway which is an important regulator of cell proliferation and anti-apoptosis (Christakos et al. 2016). Indeed, treatment of MCF7 (ER+) and MDA-MB-453 (ER-) cells with $1,25(\mathrm{OH})_{2} \mathrm{D}_{3}$ decreased expression of RAS and phosphorylation of MEK and ERK1/2. Furthermore, upregulation of RAS abrogated the antiproliferative effect of $1,25(\mathrm{OH})_{2} \mathrm{D}_{3}$ (Zheng et al. 2019). In MCF7 cells, pretreatment with $1,25(\mathrm{OH})_{2} \mathrm{D}_{3}$ sensitized to reactive oxygen species (ROS)-induced cytotoxicity through a reduction in the inner membrane potential of mitochondria, a subsequent release of cytochrome c and eventually cell death (Weitsman et al. 2005) (Fig. 1).

TP53, encoding for the tumour suppressor gene p53, is often mutated in BC cells. TP53 mutations are most common in TNBC (80\%) and HER2-positive cancers (70\%), while the prevalence is lower in patients with luminal A type (10\%) and luminal B type (30\%) BC (Duffy et al. 2018). Interestingly, several studies demonstrated that the VDR gene is a direct target of p53 and its family members (Reichrath et al. 2014). Mutant p53 (mutp53) can interact both functionally and physically with the VDR, thereby converting local vitamin D into an anti-apoptotic agent. This effect was also observed in TNBC cell lines, MDA-MB-231 and MDA-MB-468, that endogenously express mutp53R280K and mutp53R273H, respectively. The exact mechanism responsible for this conversion is not yet known, although in ovarian carcinoma cells, which endogenously express mutp53, vitamin $\mathrm{D}_{3}$ suppressed death receptor-mediated apoptosis. Indeed, additional alterations most likely cooperate with mutp53 to generate the anti-apoptotic response to vitamin $D_{3}$ (Stambolsky et al. 2010).

Next to apoptosis, treatment of BC cells with $1,25(\mathrm{OH})_{2} \mathrm{D}_{3}$ affects the autophagy pathway, a wellconserved process aimed at eliminating cellular waste products and dysfunctional organelles (Abu El Maaty \& Wolfl 2017). Mammary gland tissue is reported to lose its induced profile of autophagy during BC progression. Mechanistically, in luminal BC cells, VDR constitutively repressed the expression of $M A P 1 L C 3 B$ (LC3B), a key gene in the process of autophagy. However, treatment with $1,25(\mathrm{OH})_{2} \mathrm{D}_{3}$ partially relieved its repression (de-repressed), thereby slightly increasing its expression (TaveraMendoza et al. 2017). Another mechanism by which autophagy is induced by $1,25(\mathrm{OH})_{2} \mathrm{D}_{3}$ in MCF7 cells is via the activation of 5' AMP-activated protein kinase (AMPK) and calcium/calmodulin-dependent protein kinase 2 
(CAMKK2), both mediating calcium-induced autophagy (Hoyer-Hansen et al. 2007) (Fig. 1).

\section{Effects of $1,25(\mathrm{OH})_{2} \mathrm{D}_{3}$ on inflammation}

$1,25(\mathrm{OH})_{2} \mathrm{D}_{3}$ has well-known anti-inflammatory effects, which are mediated by stimulation of the innate and suppression of the adaptive immune system (Christakos et al. 2016).

Within the adaptive immune system, cytotoxic $\left(\mathrm{CD}^{+}\right) \mathrm{T}$ lymphocytes are important for the protection against intracellular pathogens including cancer cells. It was previously described that tumour-infiltrating $\mathrm{CD}^{+}$ lymphocytes (TILs) have anti-tumour activities that are induced by different mechanisms (Martinez-Lostao et al. 2015). Because of the anti-tumour activities of TILs, high tumour infiltration of TILs is associated with better prognosis in TNBC and HER2-enriched BC but not for $\mathrm{ER}^{+}$ BC (Stanton \& Disis 2016, Kurozumi et al. 2019, Gao et al. 2020, Oshi et al. 2020). In a recent study, the effect of vitamin $\mathrm{D}_{3}$ supplementation (cholecalciferol, $40 \mathrm{IU} /$ day) on $\mathrm{CD}^{+} \mathrm{T}$ cell infiltration was investigated using a mouse model where murine E0771 $\left(\mathrm{ER}_{\beta}{ }^{+}, \mathrm{PR}^{+}, \mathrm{HER}{ }^{+}\right)$(Le Naour et al. 2020) BC cells were injected in the mammary fat pad (Karkeni et al. 2019). Vitamin $\mathrm{D}_{3}$ supplementation reduced tumour growth and induced the number and activity of $\mathrm{CD} 8{ }^{+} \mathrm{T}$ cells within the tumour. In contrast, in high-dietary fat conditions, tumour growth was enhanced and $\mathrm{CD}^{+} \mathrm{T}$ cell infiltration was reduced after vitamin $\mathrm{D}_{3}$ supplementation.

The difference in responsiveness to vitamin $\mathrm{D}_{3}$ supplementation between low- and high-dietary fat conditions is probably due to induced expression of Cyp27a1 in the adipocytes of obese mice, which led to elevated local levels of $25(\mathrm{OH}) \mathrm{D}_{3}$ but reduced systemic levels (because $25(\mathrm{OH}) \mathrm{D}_{3}$ is diluted in a higher body volume), which could influence $\mathrm{CD} 8+\mathrm{T}$ cell infiltration. In addition, adipocytes are able to secrete pro-inflammatory cytokines such as IL-6 and CCL5. However, vitamin $\mathrm{D}_{3}$ treatment is able to limit the secretion of inflammatory cytokines from adipose tissue. These data show that the effect of vitamin $\mathrm{D}_{3}$ supplementation on tumour growth and tumour infiltration with cytotoxic $T$ cells is dependent on the fat content of the diet and demonstrated the importance of dietary intake (Karkeni et al. 2019).

Contrary to previous findings, in another $\mathrm{BC}$ mouse model where murine 4T1 (TNBC) cells were subcutaneously injected into the flanks, oral treatment with vitamin $\mathrm{D}_{3}$ resulted in accelerated tumour growth and reduced survival. In this model, vitamin $\mathrm{D}_{3}$ suppressed the $\mathrm{T}$ helper lymphocytes type 1 (Th1) response, which are TILs with important anti-tumour activities, both systemically and in the tumour microenvironment, which resulted in promotion of tumorigenesis (Cao et al. 2018) (Fig. 1).

\section{Effects of $1,25(\mathrm{OH})_{2} \mathrm{D}_{3}$ on cell metabolism}

\section{Glycolysis}

Cancer cell metabolism is characterized by an enhanced uptake of glucose, even in the presence of oxygen (the Warburg effect) (Jang et al. 2013). Aerobic glycolysis enables cancer cells to maintain their energy level and production of nucleotides, amino acids and fatty acids in order to sustain their proliferation capacity (Christakos et al. 2016).

The role of $1,25(\mathrm{OH})_{2} \mathrm{D}_{3}$ on energy metabolism is an interesting research area as alterations in cellular metabolism might explain its antiproliferative effect (Christakos et al. 2016). Studies in $\mathrm{H}$ (arvey)-rastransformed MCF10A breast epithelial cells illustrated that $1,25(\mathrm{OH})_{2} \mathrm{D}_{3}$ treatment resulted in an altered glucose consumption. More specifically, $1,25(\mathrm{OH})_{2} \mathrm{D}_{3}$ treatment reduced glycolysis and lactate production with a reduced tricarboxylic acid (TCA) cycle activity as a consequence. Treatment with $1,25(\mathrm{OH})_{2} \mathrm{D}_{3}$ reduced the flux of glucose to 3 -phosphoglycerate and resulted in decreased intracellular lactate levels by suppressing lactate dehydrogenase (LDH) activity. In addition, the glucose flux to acetyl-coA and oxaloacetate is reduced. Together, these data suggest that $1,25(\mathrm{OH})_{2} \mathrm{D}_{3}$ has a preventive role in the use of glucose for rapid proliferation during $\mathrm{BC}$ progression in a $\mathrm{H}$-ras oncogene-dependent manner (Zheng et al. 2013) (Fig. 2).

The effect of $1,25(\mathrm{OH})_{2} \mathrm{D}_{3}$ on glucose metabolism appears to be cell type-dependent. Indeed, differences in metabolic response and cellular ATP levels have been demonstrated between luminal BC (MCF7-T47D) and TNBC (MDA-MB-231) cells. However, treatment of both luminal and TNBC cell lines with $1,25(\mathrm{OH})_{2} \mathrm{D}_{3}$ upregulated the pentose phosphate pathway (PPP) and increased the expression levels of $G 6 P D$, a putative oncogene encoding the glucose-6-phosphate dehydrogenase that catalyses the first rate-limiting step of the PPP. Yet, the induction of G6PD by $1,25(\mathrm{OH})_{2} \mathrm{D}_{3}$ did not hamper the anticancer effects of genetic or pharmacological inhibition of G6PD. Treatment of MCF7 cells with $1,25(\mathrm{OH})_{2} \mathrm{D}_{3}$ resulted furthermore in increased levels of intracellular serine and ROS (Abu El Maaty et al. 2018). In addition, $1,25(\mathrm{OH})_{2} \mathrm{D}_{3}$ treatment activated the AMPK signalling in MCF7 and MDA-MB-231 cells while levels of thioredoxin-interacting protein (TXNIP), a regulator of redox balance and glucose uptake, were reduced in MCF7 cells (Abu El Maaty et al. 2018) (Fig. 2). 


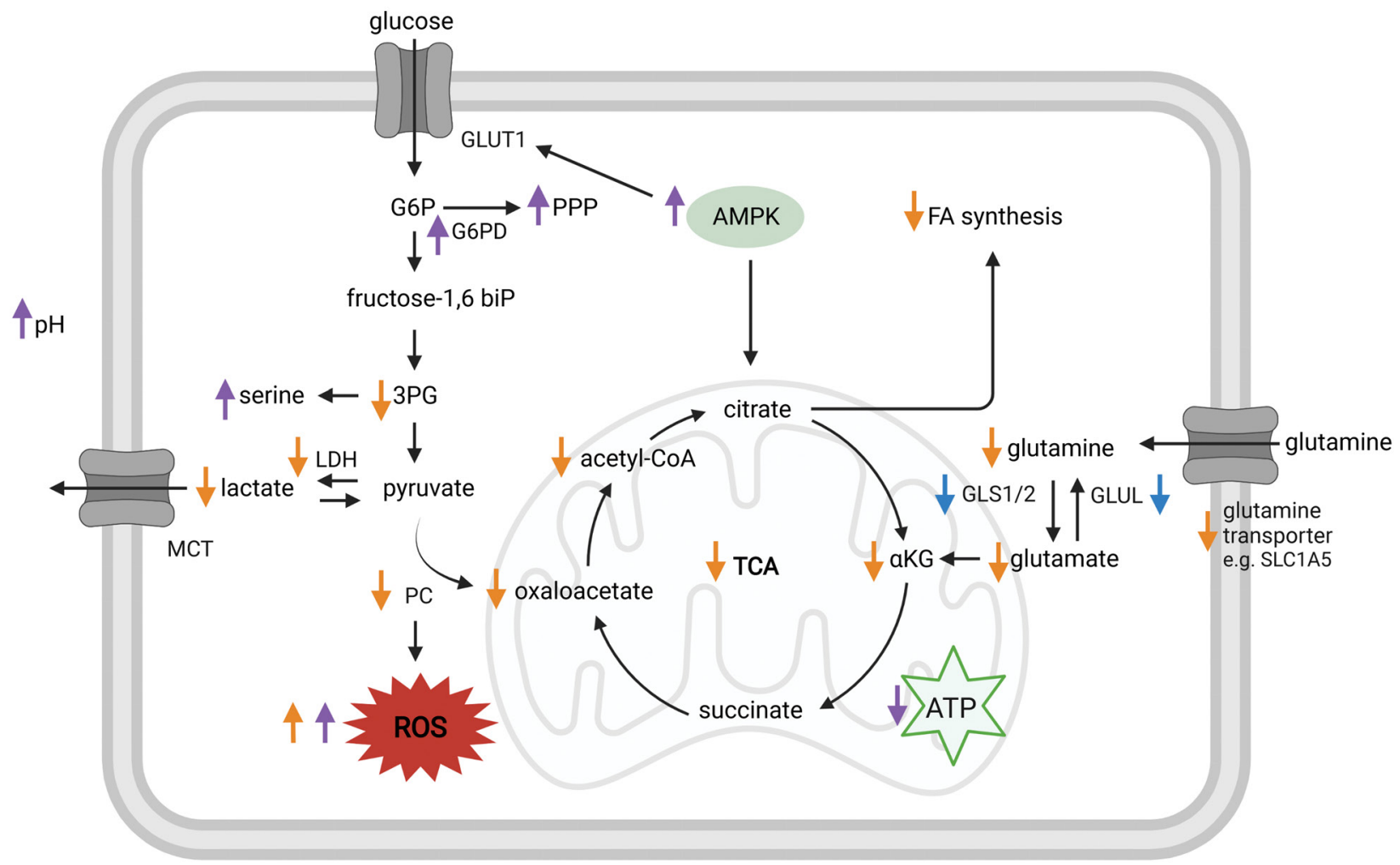

Figure 2

Overview of the effects of $1,25(\mathrm{OH})_{2} \mathrm{D}_{3}$ on cell metabolism in non-transformed mammary epithelial cells (effects shown with blue arrows), transformed mammary epithelial cells (effects shown with orange arrows) and breast cancer cells (effects shown with purple arrows). G6P, glucose 6-phosphate; G6PD, glucose-6-phosphate dehydrogenase; PPP, pentose phosphate pathway; 3PG, 3-phosphoglyceric acid; LDH, lactate dehydrogenase; MCT, monocarboxylate transporter; PC, pyruvate carboxylase; FA, fatty acid; aKG, alpha-ketoglutaric acid. Created with BioRender.com.

Similar effects of $1,25(\mathrm{OH})_{2} \mathrm{D}_{3}$ on glycolysis were recently reported in MCF7 and MDA-MB-231 cells (Santos et al. 2018). In a subsequent study, the authors demonstrated that $1,25(\mathrm{OH})_{2} \mathrm{D}_{3}$ was a potent inhibitor of the $\mathrm{V}-\mathrm{H}^{+}$-ATPase proton pump, located at the plasma membrane of metastatic cancer cells, of which the activity is regulated by glucose. Hence, the $1,25(\mathrm{OH})_{2} \mathrm{D}_{3}$-mediated decrease in glycolytic flux is suggested to contribute to the inhibition of the $\mathrm{V}-\mathrm{H}^{+}$-ATPase proton pump. As a result, the extracellular $\mathrm{pH}$ increased after treatment with $1,25(\mathrm{OH})_{2} \mathrm{D}_{3}$, disturbing the optimal $\mathrm{pH}$ for cancer cells and ultimately leading to cell death and decreased cancer progression (Santos \& Hussain 2019) (Fig. 2).

\section{Glutamine}

Treatment of H-ras-transformed MCF10A cells with $1,25(\mathrm{OH})_{2} \mathrm{D}_{3}$ reduced intracellular glutamine/glutamate and $\alpha$-ketoglutarate levels, leading to a reduced activity of the TCA cycle. Both mRNA and protein levels of the glutamine transporter, solute linked carrier family 1 , member A5 (SLC1A5), were significantly decreased after treatment with $1,25(\mathrm{OH})_{2} \mathrm{D}_{3}$. Furthermore, reporter studies identified a negative VDRE in the promotor region of the SLC1A5 gene (Zhou et al. 2016). Knockdown (KD) of SLC1A5 increased the number of apoptotic cells in H-rastransformed MCF10A cells, suggesting that targeting the glutamine pathway with vitamin D decreased BC cell growth. The effect of $1,25(\mathrm{OH})_{2} \mathrm{D}_{3}$ on glutamine metabolism was also demonstrated in non-transformed mammary epithelial cells (hTERT-HME1). Treatment of hTERT-HME1 cells with $1,25(\mathrm{OH})_{2} \mathrm{D}_{3}$ decreased the expression of glutamine synthetase (GLUL) and glutaminases (GLS1/2), reducing the amount of glutamine shunt to the TCA cycle (Beaudin \& Welsh 2017) (Fig. 2).

\section{TCA cycle}

During TCA cycle progression, pyruvate carboxylase (PC) regulates the ATP-dependent carboxylation of 
pyruvate to oxaloacetate. In $\mathrm{BC}, \mathrm{PC}$ overexpression is correlated with aggressiveness (Phannasil et al. 2017). $1,25(\mathrm{OH})_{2} \mathrm{D}_{3}$ decreased PC mRNA and protein expression and thereby induced oxidative stress in H-ras-transformed MCF10A and MCF10A-ErbB2 (HER2) breast epithelial cells (Wilmanski et al. 2017b). In addition, $1,25(\mathrm{OH})_{2} \mathrm{D}_{3}$ mediated repression of PC led to reduced synthesis of fatty acids and lipid accumulation in another transformed epithelial cell line, MCF10CA1a (Wilmanski et al. 2017a). Because a functional VDRE is described in the P2 promotor of the $P C$ gene, vitamin $D_{3}$ is suggested to be an important regulator of epithelial $\mathrm{BC}$ cell metabolism (Wilmanski et al. 2017b) (Fig. 2).

\section{Oxidative stress}

Ageing Cyp27b1 KO mice, which are deficient in circulating $1,25(\mathrm{OH})_{2} \mathrm{D}_{3}$, had increased oxidative stress and develop $\mathrm{BC}$ among other types of cancer. The increased ROS levels in these mice were accompanied by elevated DNA damage and accelerated ageing. Moreover, cellular senescence was increased in the tumour microenvironment. Interestingly, administration of $1,25(\mathrm{OH})_{2} \mathrm{D}_{3}$ prevented spontaneous tumour development in ageing Cyp27b1 KO mice, illustrating the importance of vitamin D deficiency in cancer tumorigenesis (Chen et al. 2018a). Collectively, these data illustrate that the anti-tumour effects of $1,25(\mathrm{OH})_{2} \mathrm{D}_{3}$ could - at least partially - be explained by modulating metabolic networks of BC cells (Abu El Maaty et al. 2018) (Fig. 2).

\section{Effects of $1,25(\mathrm{OH})_{2} \mathrm{D}_{3}$ on cancer stem cells}

Cancer stem cells (CSCs) were first described in acute myeloid leukaemia as a small subpopulation of cells playing an important role in tumour initiation, progression and recurrence (Bonnet \& Dick 1997, Saeg \& Anbalagan 2018). Different pathways such as the Notch, Wnt/Frizzled/ $\beta$ catenin, Hippo and Hedgehog signalling cascades are involved in the formation of CSCs and dysregulation of these pathways is linked to the development of BC. Breast CSCs are characterized by high CD44 and low CD24 expression levels (CD44+/CD24-). CD44, a cell surface adhesion receptor important for recruitment to cell surfaces, is the most commonly used marker for detection of breast CSCs (Senbanjo \& Chellaiah 2017, Saeg \& Anbalagan 2018). $\mathrm{CD} 24$ is a glycosylated cell surface protein that regulates $\mathrm{BC}$ metastasis and proliferation because it can function as an alternative ligand of P-selectin, an adhesion receptor on activated endothelial cells, which facilitates the passage of tumour cells in the blood stream during metastasis (Kristiansen et al. 2003, Jaggupilli \& Elkord 2012). As CD24 is coexisting with CD44 in different cancers, it gained new interest as CSC marker (Jaggupilli \& Elkord 2012). When Al-Hajj et al. (2003) reported that CD44+/CD24-/low cells exhibited more tumorigenic and CSC properties than CD44+/CD24+ cells, CD44+/CD24-/low was widely accepted as breast CSC marker. Next to CD44 and CD24, other markers such as aldehyde dehydrogenase-1 (ALDH-1), EpCAM, CD133 (Prominin-1) and CXCR4 are also used to detect breast CSCs (Song \& Farzaneh 2021) (reviewed in So \& Suh 2015) (Fig. 3).

Treatment of basal-like MCF710DCIS cells with a Gemini vitamin $\mathrm{D}_{3}$ analogue, BXL0124, reduced mRNA and protein expression of CD44 (So et al. 2011, Wahler et al. 2015). In addition, in TNBC SUM159 cells, $1,25(\mathrm{OH})_{2} \mathrm{D}_{3}$ and BXL0124 treatment decreased mammosphere formation, a characteristic feature of CSCs, in association with the downregulation of different CSC markers involved in their maintenance (CD44, OCT4; Notch1/2/3; JAG1/2 and NFkB) (Shan et al. 2017). The mammospheres formed after treatment with $1,25(\mathrm{OH})_{2} \mathrm{D}_{3}$ or BXL0124 had a more organized, symmetrical shape, which was similar to the spheres formed from the non-malignant cell line MCF10A (Wahler et al. 2015). More detailed analysis showed that BXL0124 inhibited the Notch1 signalling pathway in basal-like BC cells by upregulation of HES1, which is an inhibitor of JAG2, ligand for Notch1 (So et al. 2015). Recently, a transcriptomic analysis was performed in MCF10DCIS mammospheres to investigate which pathways were affected by $1,25(\mathrm{OH})_{2} \mathrm{D}_{3}$ or BXL0124 treatment. Vitamin $\mathrm{D}_{3}$ compounds reduced expression of genes involved in the maintenance of BC stem-like cells (e.g. GDF15), EMT, invasion, metastasis (e.g. LCN2 and S100A4) and chemoresistance (e.g. NGFR, PPP1R1B, and $A G R 2)$, while they upregulated genes associated with a basal-like phenotype (e.g. KRT6A and KRT5) and negative regulators of breast tumorigenesis (e.g. EMP1). More detailed pathway analysis identified TP63, a member of the TP53 family of TFs essential for epithelial stem cell development and maintenance, as a major target of vitamin $\mathrm{D}_{3}$ compounds (Shan et al. 2020).

Jeong et al. (2015) investigated the effect of vitamin $\mathrm{D}_{3}$ treatment in an MMTV-wnt1 xenograft mouse model, in which treatment with $1,25(\mathrm{OH})_{2} \mathrm{D}_{3}$ or vitamin $\mathrm{D}_{3}$ supplementation decreased tumour growth and appearance. From these tumours, CD49fhigh/Epcam ${ }^{\text {low }}$ cells were isolated and spheroid cultures were generated in vitro. Treatment of these spheroids with $1,25(\mathrm{OH})_{2} \mathrm{D}_{3}$ decreased the capacity of the cells to generate secondary spheroids, 


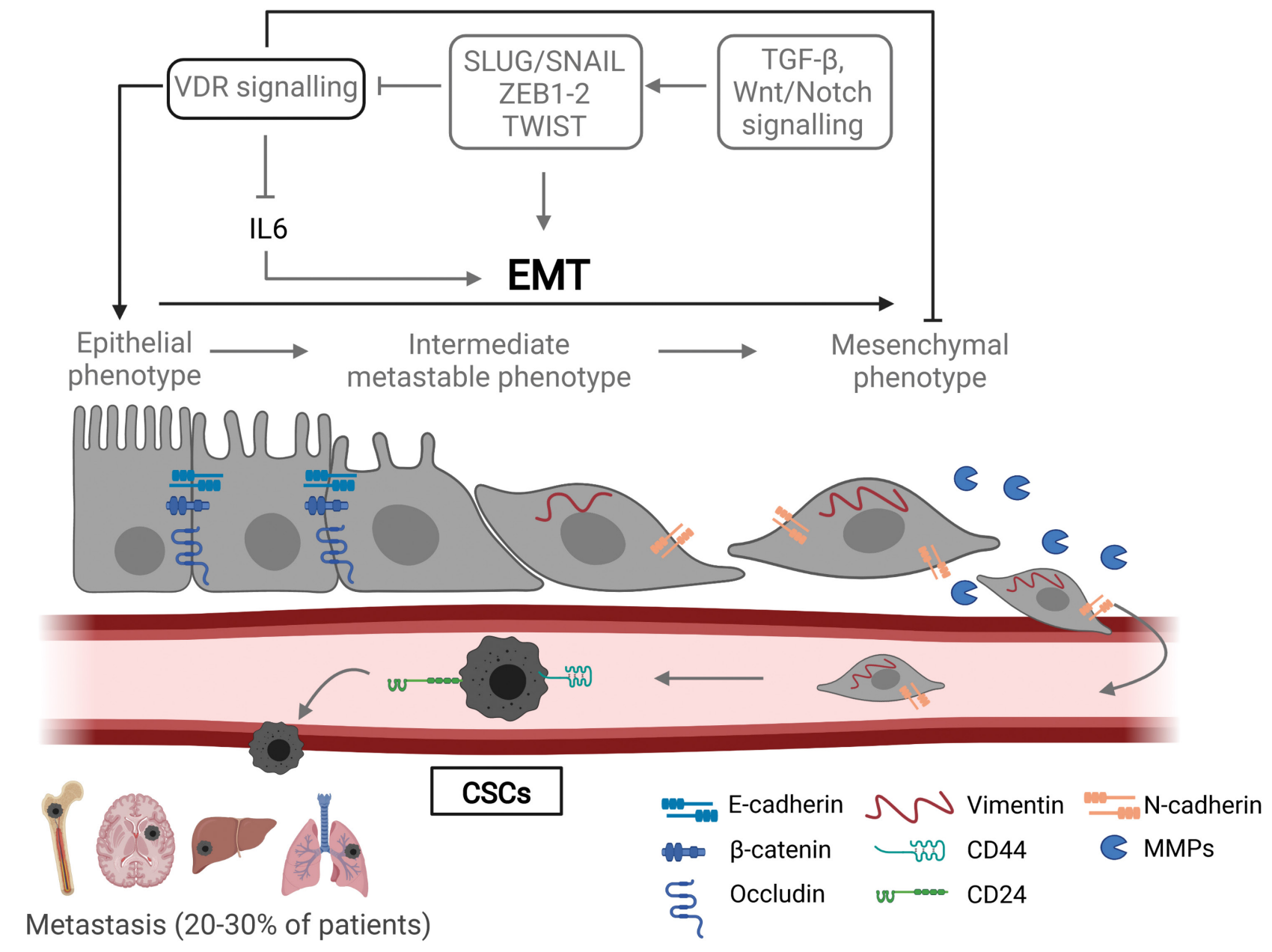

Figure 3

Schematic overview of the different effects of VDR signalling on the epithelial-mesenchymal transition process in breast cancer cells. CSCs, cancer stem cells; MMPs, matrix metalloproteinases. Created with BioRender.com.

suggesting that $1,25(\mathrm{OH})_{2} \mathrm{D}_{3}$ decreases the self-renewing capacity of CSCs in these tumours. This inhibitory effect of $1,25(\mathrm{OH})_{2} \mathrm{D}_{3}$ on CSCs is suggested to be regulated by inhibition of the Wnt/ $\beta$-catenin pathway, an important pathway for the maintenance of CSCs (Jeong et al. 2015). In MCF7 cells, treatment with $1,25(\mathrm{OH})_{2} \mathrm{D}_{3}$ inhibited Wnt $/ \beta$ catenin signalling thereby decreasing the population of CSCs (CD133+ cells) and increasing the sensitivity of MCF7 cells to therapy with the ER inhibitor tamoxifen (Zheng et al. 2018). Moreover, $1,25(\mathrm{OH})_{2} \mathrm{D}_{3}$ affects different pathways of CSC development in other types of cancer (reviewed in So \& Suh 2015, Fernandez-Barral et al. 2020).

\section{Effects of $1,25(\mathrm{OH})_{2} \mathrm{D}_{3}$ on EMT and metastasis}

In total, $20-30 \%$ of patients with early-stage BC develop metastatic disease. The most common site of metastatic lesions for $\mathrm{BC}$ is bone, followed by brain, liver and lung. However, which organ is affected by $\mathrm{BC}$ metastasis is highly dependent on the BC subtype (Chen et al. 2018b).

Tumoural VDR expression is reported to protect against $\mathrm{BC}$ metastasis in an orthotopic transplantation model of murine 168FARN BC cells, in which $V d r$ expression was silenced with shRNA. Tumours from $V d r$ KD cells not only grew significantly faster than tumours from control or $V d r$ rescue cells but also metastasized to the liver. Gene analysis identified Id1 (DNA-binding protein inhibitor ID-1) as a direct mediator of VDR signalling in murine BC cells, and this relationship was confirmed in humans (Williams et al. 2016).

An important process in the formation of metastatic lesions is EMT. During this process, epithelial cells lose their cell-cell and cell-matrix junctions and undergo a change in gene signature (downregulation of epithelial genes- 
upregulation of mesenchymal genes) to eventually convert into mesenchymal cells (Larriba et al. 2016) (Fig. 3). The EMT process is activated by different agents and signals, such as the TGF- $\beta$, Wnt and Notch signalling, which activate TFs that are important for EMT (EMT-TFs) (FernandezBarral et al. 2020). These EMT-TFs include the zinc finger proteins SNAIL1 and SNAIL2, the double zinc finger and homeodomain ZEB1 and ZEB2 as well as TWIST1 and E47, members of the basic-helix-loop family (Larriba et al. 2016). Proteins important for cell adhesion include E-cadherin (hallmark of the epithelial phenotype), the tight junction proteins claudins, occludins and cytokeratins. The mesenchymal phenotype has more fibroblastic-like characteristics with markers such as $\mathrm{N}$-cadherin, vimentin and matrix metalloproteases (MMPs) (Fig. 3).

An association between vitamin D signalling and the EMT process was demonstrated by the finding that the EMT-TF SLUG, member of the SNAIL zinc finger family, repressed the $V D R$ gene in human $\mathrm{BC}$ cells, and reduced their sensitivity to the anti-tumour activity of $1,25(\mathrm{OH})_{2} \mathrm{D}_{3}$. Indeed, introduction of SLUG expression in MDA-MB-468 and MCF7 cells resulted in significant reduction of VDR levels. Moreover, the invasive TNBC BT549 cell line has a high SLUG expression, whereas VDR is not expressed (Mittal et al. 2008).

In an MDA-MB-231 xenograft mouse model, downregulation of miR-1204 decreased distant metastasis not only by reducing cell proliferation after increased VDR expression as described above but also by downregulation of mesenchymal markers (N-cadherin/vimentin), which reduces the EMT process. The critical role of the VDR in the process of EMT was also demonstrated in vivo by injecting MDA-MB-231 cells expressing anti-miR-1204 into nude mice. In these mice, silencing of the VDR increased tumour growth and distal metastasis (Liu et al. 2018).

The induction of epithelial markers such as E-cadherin represents an additional mechanism by which $1,25(\mathrm{OH})_{2} \mathrm{D}_{3}$ regulates the EMT process and may inhibit cancer progression (Larriba et al. 2016). Also, in TNBC MDA-MB-231 cells, $1,25(\mathrm{OH})_{2} \mathrm{D}_{3}$ upregulates E-cadherin by $C D H 1$ promoter demethylation (Lopes et al. 2012a) (Fig. 3). Furthermore, $1,25(\mathrm{OH})_{2} \mathrm{D}_{3}$ decreased the bone metastatic potential of MCF10CA1a and MDA-MB-231 cells as illustrated in an in vitro metastasis model. Also, an increased expression of the epithelial marker E-cadherin and decreased expression of $\mathrm{N}$-cadherin suggested a decrease in the process of EMT (Wilmanski et al. 2016).

A recent study described the effect of dietary vitamin $\mathrm{D}_{3}$ deficiency on the CXCL12-CXCR4 axis in MMTV-PyMT mice. CXCL12 is a chemokineinvolved in cancer progression and increased levels are associated with poor prognosis in BC patients. The receptor of CDXL12, CXCR4, is involved in tumour growth and metastasis. The MMTV-PyMT mouse model spontaneously develops distant metastasis in the lung after 9-10 weeks on a normal diet. However, when mice were fed a vitamin $\mathrm{D}_{3}$-deficient diet, lung metastasis arose already from 8 weeks. Li et al. have demonstrated that vitamin $\mathrm{D}_{3}$ deficiency increased the levels of EMT markers (ZEB1) in the primary tumour tissue and CXCL12 expression in the metastatic long stromal tissue. In addition, vitamin $\mathrm{D}_{3}$ deficiency enhanced CXCL12/CXCR4 colocalization in the lung metastatic tumours, which enhances metastasis formation (Li et al. 2021a).

Furthermore, VDR KD in MDA-MB-231 BC cells promoted cancer cell motility and invasiveness and elevated the bone metastatic potential of MDA-MB-231 cells. VDR KD in MDA-MB-231 cells was accompanied by a reduced expression of epithelial markers such as $\beta$-catenin, E-cadherin and F-actin, while mesenchymal markers such as vimentin were increased. These results show that loss of $V D R$ expression in MDA-MB-231 cells induced EMT progression and facilitated the formation of tumour colonies in bone (Horas et al. 2019) (Fig. 3).

In contrast, in young (6-8 weeks old) BALB/cfemale mice, treatment with $1,25(\mathrm{OH})_{2} \mathrm{D}_{3}$ and its lowcalcaemic analogues, PRI-2191 and PRI-2205, enhanced the metastatic potential of 4T1 mouse mammary gland cancer cells to the lung without affecting the primary tumour. In tumours from treated mice, osteopontin (OPN, Spp1) secretion was increased (pro-metastatic), while TGF $\beta$ $(T g f b)$ levels were decreased (anti-metastatic). Additionally, treatment with $1,25(\mathrm{OH})_{2} \mathrm{D}_{3}$ and analogues increased the expression of mesenchymal markers such as SNAIL1 and N-cadherin during tumour progression, whereas E-cadherin expression decreased (Anisiewicz et al. 2018). Further analysis of the immune response in splenocytes and lymph nodes of these mice showed an increased response of $\mathrm{T}$ helper lymphocytes type 2 (Th2) with increased activity of regulatory $\mathrm{T}$ (Treg) lymphocytes, suggesting that both analogues have an immunosuppressive effect in these mice. Also, the expression of $S p p 1$ and $T g f b$ in the lung was upregulated by the treatment and was responsible for the immunosuppressive metastatic niche formation (Pawlik et al. 2018). In contrast to these findings, the same research group showed that in old ovariectomized (OVX) mice, $1,25(\mathrm{OH})_{2} \mathrm{D}_{3}$ and both its analogues reduced the metastatic spread of $4 \mathrm{~T} 1$ breast carcinoma cells to the lung by decreasing OPN levels. Also, in aged OVX mice, $1,25(\mathrm{OH})_{2} \mathrm{D}_{3}$ and analogue treatment decreased bone mineralization while this effect was not seen in young mice 
(Anisiewicz et al. 2019). These data suggest that the activity profile of $1,25(\mathrm{OH})_{2} \mathrm{D}_{3}$ and analogues is dependent on the age of the mice. However, the researchers do not provide an explanation for the finding that old OVX treated mice responded differently to vitamin $\mathrm{D}_{3}$ treatment than young mice. Important to note is that 4T1 cells are not responsive to $1,25(\mathrm{OH})_{2} \mathrm{D}_{3}$ treatment in vitro or in vivo, as primary tumour growth was not affected. This suggests that the antimetastatic effects of $1,25(\mathrm{OH})_{2} \mathrm{D}_{3}$ and analogues were induced by cells in the tumour microenvironment such as fibroblasts or immune cells. Also, previous studies with the same model (4T1) have shown conflicting results regarding the effect of $1,25(\mathrm{OH})_{2} \mathrm{D}_{3}$ or analogue treatment on primary tumour growth and metastatic formation. Zhang et al. (2014) reported a decrease in the number of lung metastases in 4T1-tumor bearing mice after $1,25(\mathrm{OH})_{2} \mathrm{D}_{3}$ treatment, while Cao et al. (2018) reported a stimulation of primary tumour growth after treatment with vitamin $\mathrm{D}_{3}$ in an 4T1-subcutaneous mouse model. However, the difference in results could be explained by the different treatment schedules used. Zhang et al. (2014) used an orthotopic model and treated the mice IP once every other day with $1,25(\mathrm{OH})_{2} \mathrm{D}_{3}$ at a dose of $0.3 \mu \mathrm{g} / \mathrm{kg}$ body weight during 8 weeks while Cao et al. (2018) used a subcutaneous model and treated the mice daily through gavage with vitamin $\mathrm{D}_{3}$ at a dose of $5 \mu \mathrm{g} / \mathrm{kg}$ during 7 days.

Finally, $1,25(\mathrm{OH})_{2} \mathrm{D}_{3}$ also influences EMT by inhibiting inflammatory cytokines such as IL-6. Previously, Sullivan et al. (2009) have shown that IL-6 induces EMT by activation of STAT3 and downregulation of E-cadherin in ER+ BC cells. In vitro analysis of HCC1806 TNBC cells demonstrated that combined treatment with IL- 6 and $1,25(\mathrm{OH})_{2} \mathrm{D}_{3}$ suppressed the inhibitory effect of $1,25(\mathrm{OH})_{2} \mathrm{D}_{3}$ on EMT and stemness as E-cadherin was more upregulated after treatment with $1,25(\mathrm{OH})_{2} \mathrm{D}_{3}$ alone, while IL-6 had no effect on E-cadherin expression (Abdel-Mohsen et al. 2019). Since IL-6 is known to be secreted by adipocytes into the tumour microenvironment in $\mathrm{BC}$, it may impair the anticancer effect of $1,25(\mathrm{OH})_{2} \mathrm{D}_{3}$. However, the exact interplay between IL- 6 and $1,25(\mathrm{OH})_{2} \mathrm{D}_{3}$ was not investigated by the researchers. The downregulation of CYP27B1 by IL-6, as was observed in colon cancer cells, may contribute to these antagonizing effects of IL-6 (Hummel et al. 2014) (Fig. 3).

\section{Combination therapies with $1,25(\mathrm{OH})_{2} \mathrm{D}_{3}$ or analogues}

As $1,25(\mathrm{OH})_{2} \mathrm{D}_{3}$ and vitamin $\mathrm{D}_{3}$ analogues reduce tumour progression by blocking different pathways, multiple studies investigated possible combinations of approved chemotherapies or other compounds with $1,25(\mathrm{OH})_{2} \mathrm{D}_{3}$ or vitamin $\mathrm{D}_{3}$ analogues to find a synergistic combination therapy.

As it was previously shown that $1,25(\mathrm{OH})_{2} \mathrm{D}_{3}$ treatment decreased ER $\alpha$ protein and mRNA levels in MCF7 cells (Swami et al. 2000) and aromatase expression in MCF7 tumour xenografts and surrounding adipose tissue (Krishnan et al. 2010), the combination of $1,25(\mathrm{OH})_{2} \mathrm{D}_{3}$ with endocrine therapy such as aromatase inhibitors (anastrozole and letrozole) was investigated in an MCF7 xenograft mouse model. Combined treatment with anastrozole was able to significantly reduce tumour volume compared to mono-treatment, and the combination with letrozole significantly decreased tumour volume compared to vehicle treatment (Swami etal. 2011) (Table 2). This suggests that $1,25(\mathrm{OH})_{2} \mathrm{D}_{3}$ improves the sensitivity to endocrine therapy such as aromatase inhibitors. The combination of $1,25(\mathrm{OH})_{2} \mathrm{D}_{3}$ with the anti-oestrogen compound tamoxifen showed additive anti-proliferative effects in MCF7 cells (Vinkvan Wijngaarden et al. 1994). Also in vivo, combination of tamoxifen with the vitamin $\mathrm{D}_{3}$ analogue 22-oxa-calcitriol (OCT) showed synergistic anti-tumour effects in an MCF7 xenograft model (Abe-Hashimoto et al. 1993) (Table 2). Interestingly, combined targeting of the VDR and the androgen receptor (AR) with agonists proved effective in $\mathrm{VDR}^{+}$and $\mathrm{AR}^{+} \mathrm{TNBC}$ cells by decreasing cell viability, which was even further decreased in combination with chemotherapy (Thakkar et al. 2016) (Table 2). Recently, small molecules affecting cell proliferation and/or cell death pathways were investigated in combination with $1,25(\mathrm{OH})_{2} \mathrm{D}_{3}$ or vitamin $\mathrm{D}_{3}$ analogues. One such molecule, ruxolitinib, a Janus kinase (JAK) 1 and JAK2 inhibitor, reduced cell proliferation synergistically in combination with $1,25(\mathrm{OH})_{2} \mathrm{D}_{3}$ in an MCF7-HER18 (ER $\left.{ }^{+}, \mathrm{HER} 2^{+}\right)$BC model by activation of apoptosis and sub-G1 arrest (Lim et al. 2018). Other small molecules such as lapatinib and neratinib, inhibitors of tyrosine kinase activity of the ERBB family (EGFR, HER2 and HER4), inhibited cell growth as well as AKT and ERK phosphorylation (pathways activated by ERBB family members) more effectively after combination with the vitamin $\mathrm{D}_{3}$ analogue, EB1089, in EGFR and/or HER2+ breast cancer cell lines. In addition, apoptosis was increased after these combination treatments in both 2D and 3D cultures (Segovia-Mendoza et al. 2017). In the same subset of BC cell lines, the same group analysed the combination of $1,25(\mathrm{OH})_{2} \mathrm{D}_{3}$ and vitamin $\mathrm{D}_{3}$ analogues, calcipotriol and EB1089, with another tyrosine kinase inhibitor, gefitinib. 


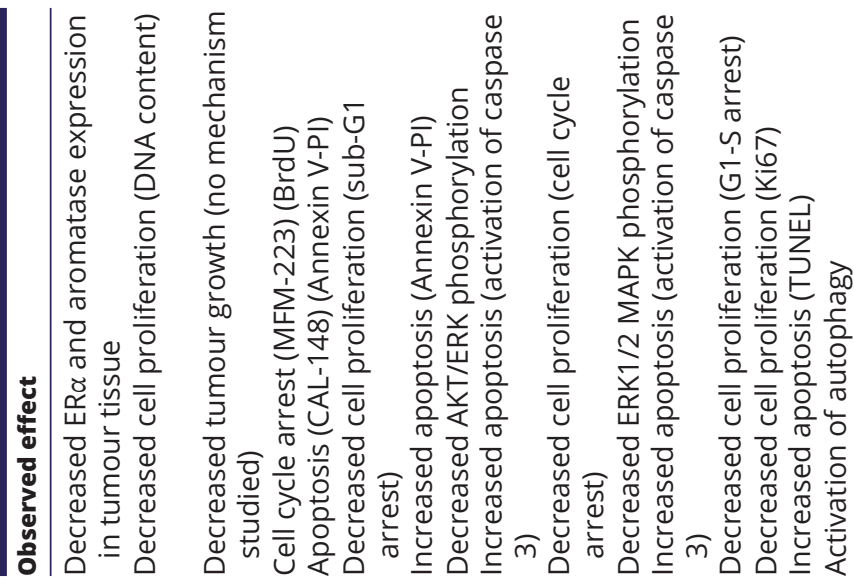

음

$\stackrel{\text { N }}{\supset}$

I $\stackrel{E}{E}$

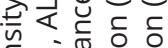

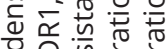

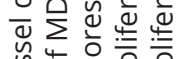

ᄃ

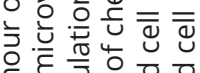

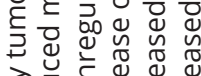

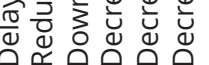

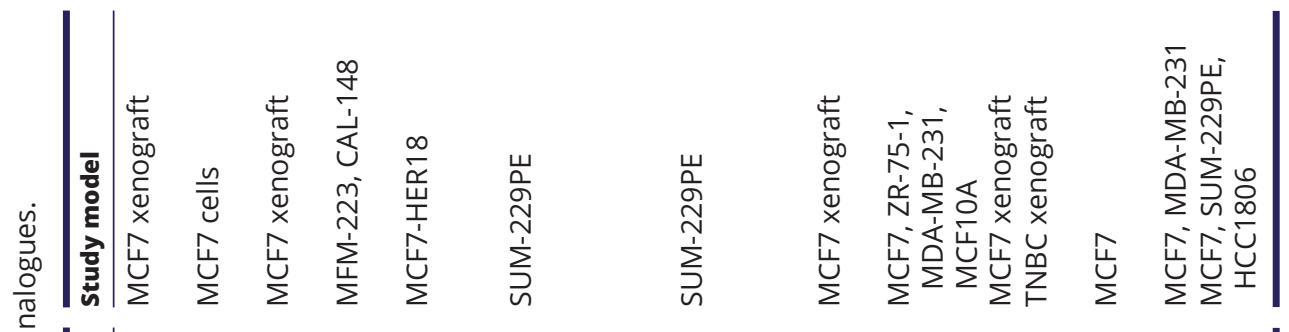

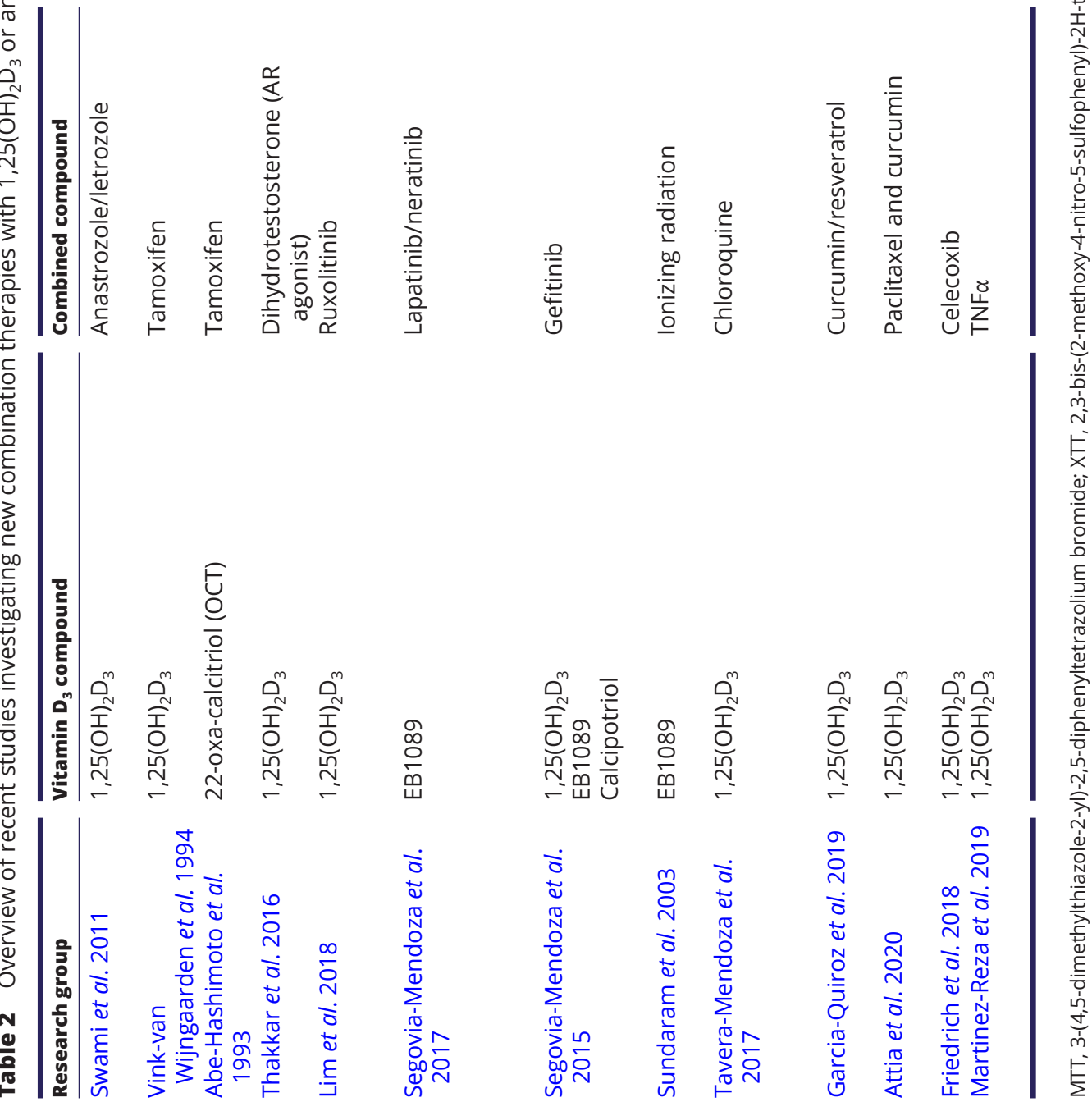


Again, the growth inhibitory effect of the combination therapy $\left(1,25(\mathrm{OH})_{2} \mathrm{D}_{3} /\right.$ vitamin $\mathrm{D} 3$ analogues and gefitinib) was elicited by downregulation of ERK1/2 MAPK signalling and induction of apoptosis by upregulation of BIM and caspase 3 (Segovia-Mendoza et al. 2015) (Table 2). The same vitamin $\mathrm{D}_{3}$ analogue, EB1089, combined with ionizing radiation reduced tumour growth in an MCF7 breast tumour xenograft model by promoting apoptotic cell death (Sundaram et al. 2003) (Table 2).

Also, chloroquine, an inhibitor of autophagosome acidification, synergistically inhibited cell proliferation in combination with $1,25(\mathrm{OH})_{2} \mathrm{D}_{3}$ in MCF7 cells not only in vitro but also in vivo. The size of tumour xenografts was substantially smaller after the combination treatment than after the mono-treatment (Tavera-Mendoza et al. 2017) (Table 2).

In addition, combining $1,25(\mathrm{OH})_{2} \mathrm{D}_{3}$ with curcumin or resveratrol, both angiogenesis blockers, potentiated the action of $1,25(\mathrm{OH})_{2} \mathrm{D}_{3}$ by facilitating the heterodimerization of VDR with RXR, resulting in a cooperative effect on gene transactivation (GarciaQuiroz et al. 2019). In an MBCDF-T TNBC xenograft model, combination therapy of $1,25(\mathrm{OH})_{2} \mathrm{D}_{3}$ with curcumin delayed tumour onset and reduced tumour volume and microvessel density. In addition, tumour endothelial cells were less activated as illustrated by reduced expression and activity of the vitronectin receptor $(\alpha v \beta 3)$ in the combination groups of $1,25(\mathrm{OH})_{2} \mathrm{D}_{3}$ with curcumin or resveratrol (Garcia-Quiroz et al. 2019). The combination of curcumin with $1,25(\mathrm{OH})_{2} \mathrm{D}_{3}$ was also investigated in MCF7 cells in vitro, in combination with paclitaxel. The triple combination reduced gene and protein expression of resistance markers such as multidrug resistance complex 1 (MDR-1) and ALDH-1, suggesting that the addition of curcumin and $1,25(\mathrm{OH})_{2} \mathrm{D}_{3}$ enhanced the tumour response to paclitaxel treatment by decreasing chemoresistance (Attia et al. 2020) (Table 2).

Another target important in the process of inflammation is cyclooxygenase 2 (COX2). $1,25(\mathrm{OH})_{2} \mathrm{D}_{3}$ was combined with the COX2 inhibitor, celecoxib, in MCF7 and MDA-MB-231 cells, causing a synergistic growth inhibitory effect in both $\mathrm{BC}$ cell lines (Friedrich et al. 2018). Interestingly, $1,25(\mathrm{OH})_{2} \mathrm{D}_{3}$ regulated the production and secretion of cytokines such as IL-1 $\beta$ and TNF- $\alpha$ in TNBC SUM-229PE cells. Moreover, when combining $1,25(\mathrm{OH})_{2} \mathrm{D}_{3}$ with TNF- $\alpha$, the combination was more potent to reduce cell proliferation than either compound alone, probably by potentiating the cytotoxic effect of TNF- $\alpha$ on BC cells (MartinezReza et al. 2019) (Table 2).

\section{Epidemiological studies of vitamin D and breast cancer}

In the 1980s, the association between sunlight exposure and cancer incidence was suggested based on the observation that geographical areas located far from the equator have a higher incidence of cancer, which could be associated with a decrease in sunlight exposure or vitamin D status (Garland et al. 1990, 2006). This association was further analysed in epidemiological studies in which baseline 25(OH)D levels were measured before start of any treatment (Bilinski \& Boyages 2013). Vitamin D deficiency is often seen in BC patients at diagnosis (Peppone et al. 2011, Karthikayan et al. 2018, Machado et al. 2019) and can be correlated to BC subtype, as patients with higher tumour grade, non-luminal and ER- BCs have lower serum 25(OH)D levels than their opposing groups (Peppone et al. 2012, Karthikayan et al. 2018).

\section{Observational studies}

Observational studies were set up to investigate a possible causal relationship between different factors such as 25(OH)D levels and vitamin D intake on BC risk, survival and progression. However, these studies often lack sufficient power to prove any association. Therefore, metaanalyses were set up to further investigate this relationship by combining different studies conducted in a specific time frame. Recently, such meta-analysis studies described the association between serum $25(\mathrm{OH}) \mathrm{D}$ levels and $\mathrm{BC}$ risk and survival (Vaughan-Shaw et al. 2017, Estebanez et al. 2018, Song et al. 2019, Hossain et al. 2019). A protective effect of 25(OH)D levels on BC development was reported in pre-menopausal women (Estebanez et al. 2018), whereas a different meta-analysis described a $6 \%$ decrease in $\mathrm{BC}$ risk when blood vitamin D levels increased by $5 \mathrm{nmol} / \mathrm{L}$ in both pre-and post-menopausal women (Song et al. 2019). However, no association between vitamin D intake and $\mathrm{BC}$ risk or development was found in those studies (Estebanez et al. 2018, Song et al. 2019). In addition, another meta-analysis pointed to an association between higher 25(OH)D levels and reduced risk of BC death and disease progression (Vaughan-Shaw et al. 2017). In contrast, Hossain et al. (2019) did not confirm this association, they did however report an association between vitamin $\mathrm{D}$ deficiency and $\mathrm{BC}$ occurrence. As vitamin $\mathrm{D}$ deficiency is often more pronounced in African women, the effect of vitamin D supplementation was specifically investigated in this group of patients. An inverse association between vitamin D supplementation and BC risk was found, with 
the strongest effect for TNBC in Black individuals. Increased sun exposure was also associated with reduced cancer risk in specific BC subtypes: $\mathrm{ER}^{+}, \mathrm{ER}^{-}$and TNBC among Black women (Qin et al. 2020). Although observational studies and their meta-analyses often suggest an association between serum 25(OH)D and BC risk, it remains difficult to prove the causal relationship between vitamin D deficiency and BC risk (Bilinski \& Boyages 2013, Feldman et al. 2014).

\section{Mendelian randomization studies}

Another way to investigate the effect of vitamin D status on $\mathrm{BC}$ risk is by performing Mendelian randomization (MR) studies. These studies analyse the association between single-nucleotide polymorphisms (SNPs) in different genes important in the vitamin D pathway and BC risk. Previously, genetic variants in four genes (GC (vitamin D binding protein), DHCR7 (7-dehydrocholesterol reductase), CYP2R1 and CYP24A1) of the vitamin D signalling pathway were associated with plasma $25(\mathrm{OH}) \mathrm{D}$ concentrations. Recently, large-scale genome-wide association studies (GWAS) were performed in 79,366 individuals, which identified 2 additional loci (SEC23A and AMDHD1) associated with serum 25(OH)D levels (Jiang et al. 2018). These 6 loci were then further analysed in 122,977 breast cancer cases, but no association between the genetic variants and $\mathrm{BC}$ risk could be observed (Jiang et al. 2019). The latest MR analysis of the same group investigated 138 SNPs in 69 vitamin D-associated loci. Again, there was no evidence for a causal effect of $25(\mathrm{OH}) \mathrm{D}$ concentrations on BC risk (Jiang et al. 2021). Despite the increased power of the recent studies performed, until now, no causal association between reduced circulating vitamin D levels and BC risk could be proven (Bouillon et al. 2019).

\section{Randomized controlled trials}

To prove a causal role between vitamin $\mathrm{D}$ and breast cancer risk, response rate or survival, randomized controlled trials (RCTs) with sufficient power are needed. Recently, the VITamin D and OmegA-3 TriaL (VITAL) was finalized, which is one of the biggest RCTs conducted until now with 25,871 subjects included. This randomized, doubleblind, placebo-controlled, $2 \times 2$ factorial clinical trial investigated the effect of daily vitamin $\mathrm{D}_{3}$ supplementation (2000 IU) alone or combined with marine n-3 (1 g) supplementation, on the prevention of cancer. Of the 25,871 trial participants, $51 \%$ were women and the mean age of the participants was 67.1 years. In the cohort, $20 \%$ of the participants were Black and 71\% were self-declared
non-Hispanic White participants. At baseline, the mean $25(\mathrm{OH}) \mathrm{D}$ level was $30 \pm 10 \mathrm{ng} / \mathrm{mL}$, and after 1 year, the mean $25(\mathrm{OH}) \mathrm{D}$ level increased to $41.8 \mathrm{ng} / \mathrm{mL}$ in the vitamin $\mathrm{D}_{3}$ group, while there was a minimal change in the placebo group (subgroup analysis of 1644 participants). In the first analysis, where vitamin $\mathrm{D}_{3}$ supplemented patients were compared with placebo controls, the VITAL study did not find any difference in BC incidence between those groups (Manson et al. 2019) (Table 3). Cancer was confirmed based on histological or cytological data.

However, in a secondary analysis, focusing on the incidence of advanced cancers (metastatic or fatal) and after correcting for BMI, a significant risk reduction was found in the vitamin $\mathrm{D}_{3}$-supplemented group compared to the placebo control group. The strongest risk reduction for advanced cancers was seen in the normal weight group (BMI <25) after supplementation with vitamin $\mathrm{D}_{3}$. Stratification by race did not change the risk for total metastatic or fatal cancer between vitamin $\mathrm{D}_{3}$ or placebo group (Chandler et al. 2020).

A similar RCT conducted by Lappe et al. (2017) aimed at investigating the effect of the same amount of vitamin $\mathrm{D}_{3}$ supplementation (2000 IU/day) but combined with calcium supplementation $(1500 \mathrm{mg} /$ day $)$ instead of supplementation with fatty acids. A total of 2303 postmenopausal women were investigated for 4 years, but again, supplementation with vitamin $\mathrm{D}_{3}$ and calcium did not significantly reduce all-type cancer risk over a period of 4 years (Lappe et al. 2017) (Table 3). Recently, in the vitamin $\mathrm{D}$ assessment (ViDa) study, a double-blind placebocontrolled trial, the effect of monthly supplementation with vitamin $\mathrm{D}_{3}$ (100,000 IU) on the incidence of acute and chronic diseases was investigated. Also, this study did not support any effect of vitamin $\mathrm{D}_{3}$ supplementation on overall cancer incidence (Scragg 2019) (Table 3). In another RCT, high-dose vitamin $\mathrm{D}_{3}$ supplementation (40,000 IU/day) was given to patients prior to breast cancer surgery to analyse its effect on cell proliferation (Ki67) and apoptosis (cleaved caspase 3). After 2-6 weeks of daily supplementation, there was no effect on BC cell proliferation and apoptosis, despite increased levels of 25(OH)D (Arnaout et al. 2019) (Table 3). Also, the study of Crew et al. (2019) examining vitamin $\mathrm{D}_{3}$ supplementation (20,000 IU/week) in high-risk premenopausal women failed to show a reduced BC risk after 12 months of treatment, as assessed by mammographic density (Table 3 ). The latter is a well-established predictor for BC risk, as women with higher breast density ( $75 \%$ or more) have four to six times more risk to develop breast cancer (Yaghjyan et al. 2012). In addition, meta-analysis studies performed on eight and
(C) 2022 Society for Endocrinology Published by Bioscientifica Ltd. Printed in Great Britain 

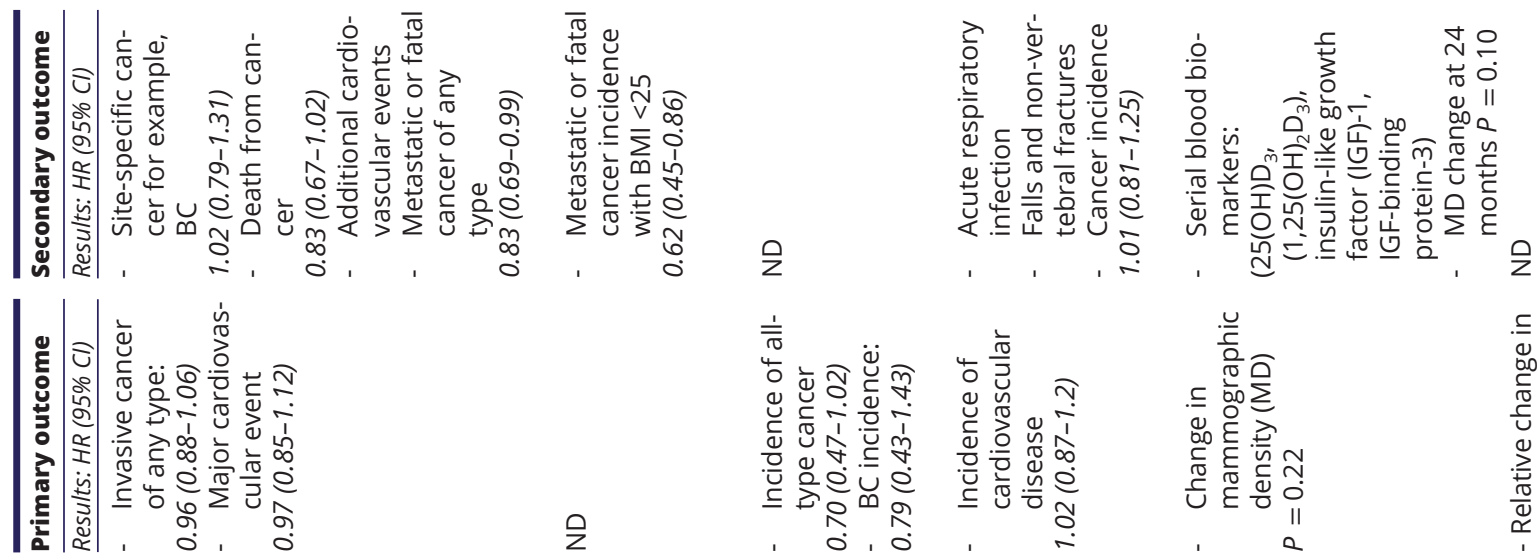

○

之
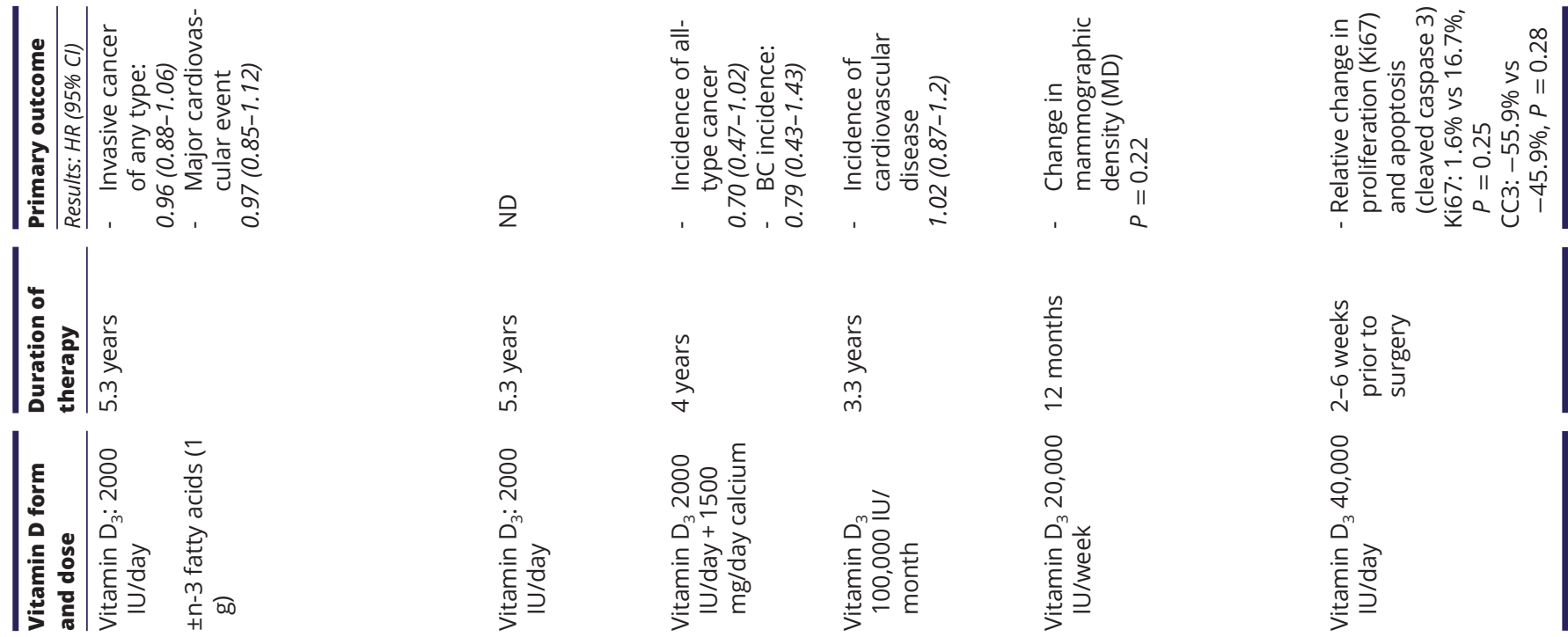

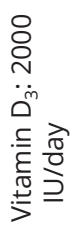
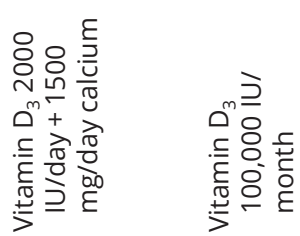

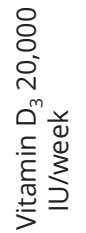
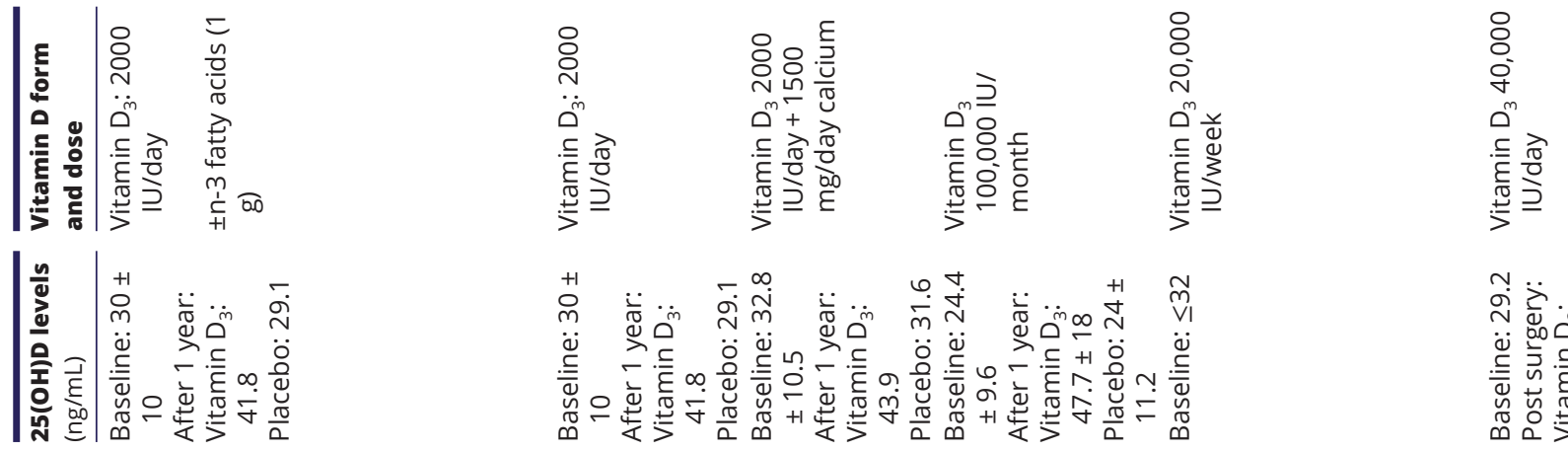

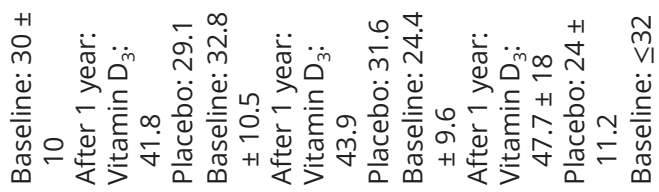

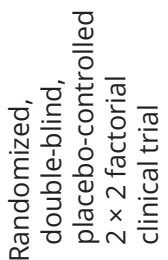
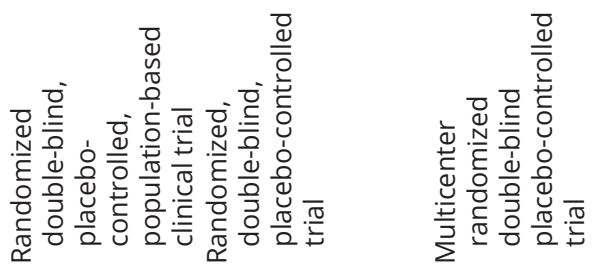

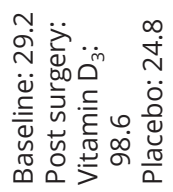
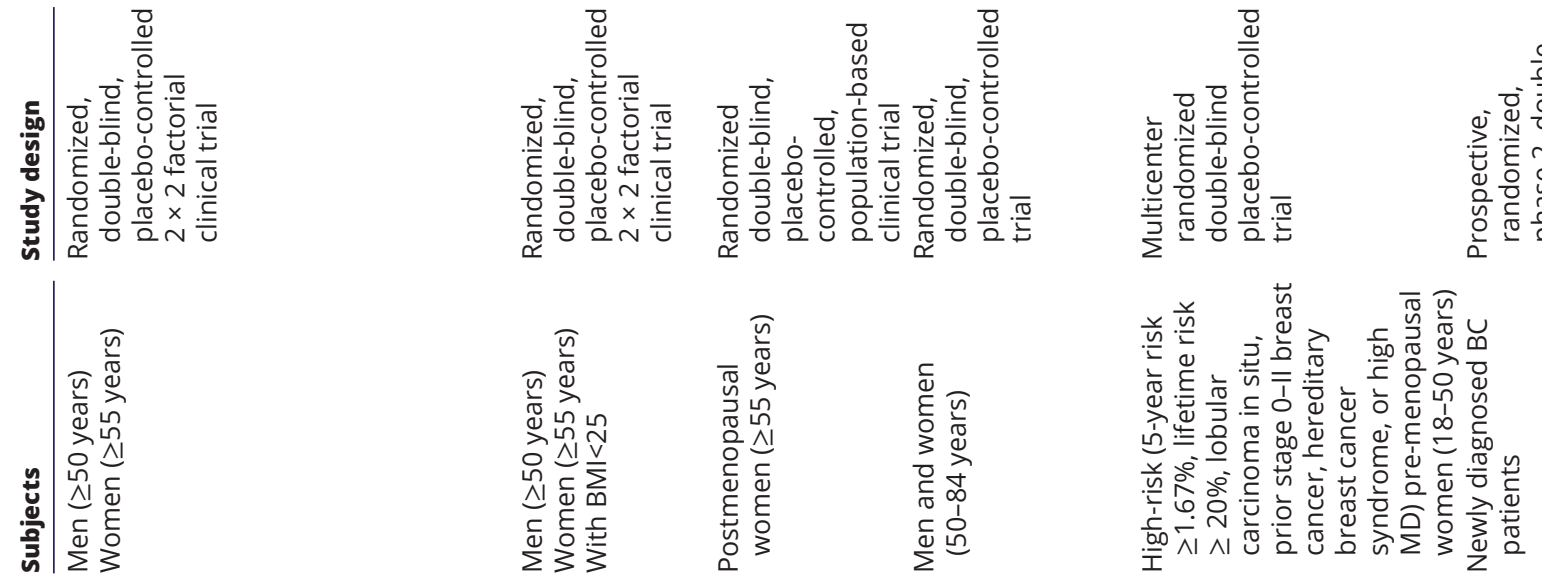

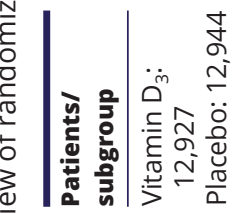
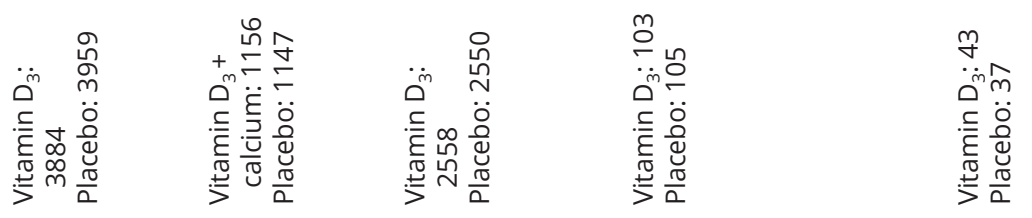

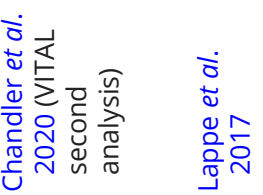

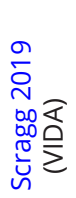

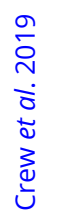
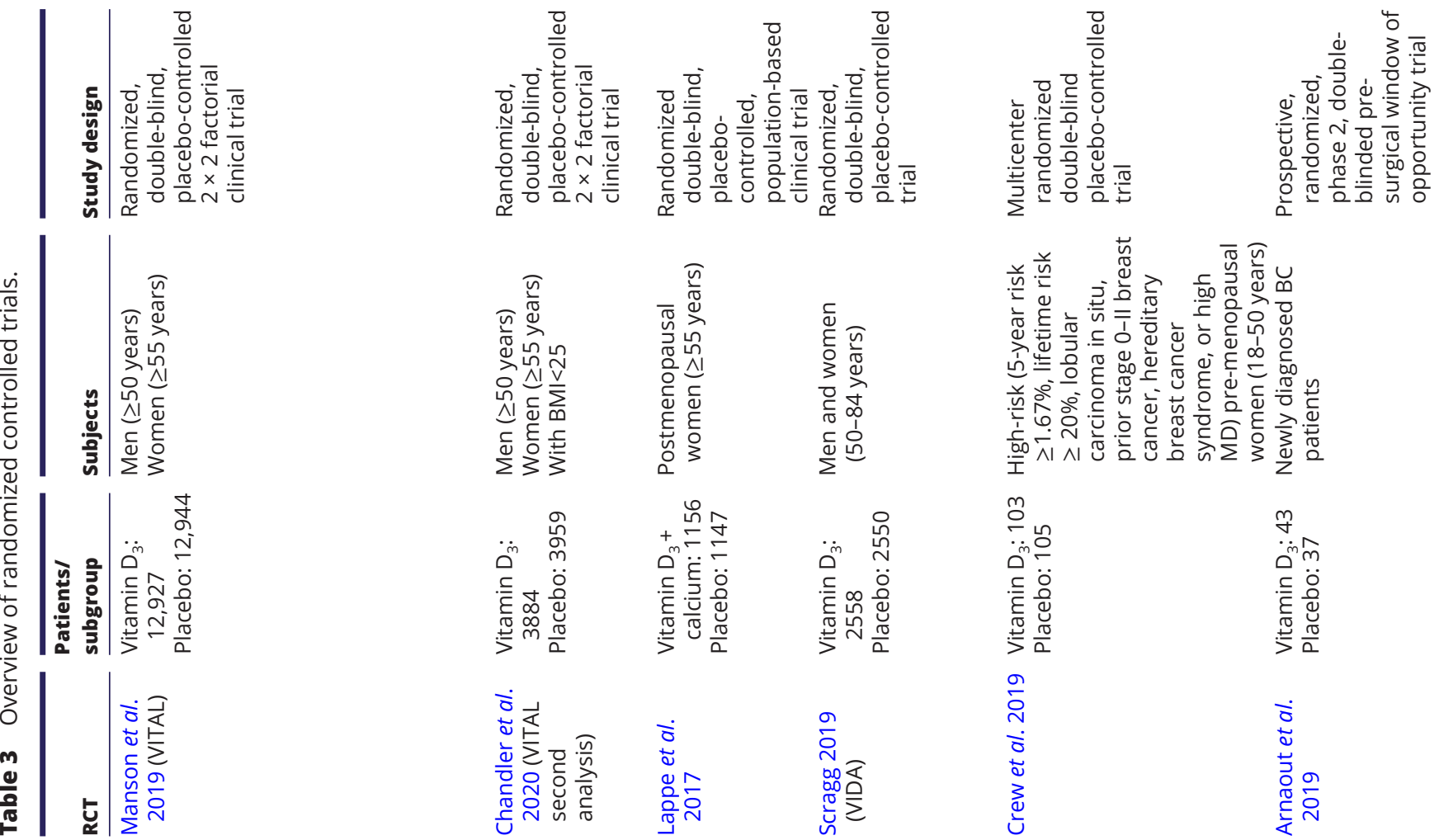
seven pooled RCTs could not prove any association between vitamin $\mathrm{D}_{3}$ supplementation and BC risk (Zhou et al. 2020, Li et al. 2021b). During the last 5 years, no RCTs investigated the effect of vitamin $\mathrm{D}_{3}$ supplementation on $\mathrm{BC}$ survival or response rate. Currently, one clinical trial is evaluating the effect of neoadjuvant vitamin $\mathrm{D}_{3}$ administration on DFS (5 years) in locally advanced BC (NCT01608451; ClinicalTrials.gov). Another study currently evaluates the effect of adding weekly vitamin $\mathrm{D}_{3}$ supplementation $(50,000 \mathrm{IU})$ to neoadjuvant therapy on pathological complete response (NCT03986268; ClinicalTrials.gov).

So, until now, RCTs do not support any effect for vitamin $\mathrm{D}_{3}$ supplementation on $\mathrm{BC}$ risk or incidence. However, as vitamin $\mathrm{D}_{3}$ is a nutrient, a lot of confounders will influence the results of vitamin $\mathrm{D}_{3}$ RCTs. There is still discussion on the optimal threshold for $25(\mathrm{OH}) \mathrm{D}$ and the optimal supplementation dose for vitamin $\mathrm{D}_{3}$ (daily/monthly). In addition, the continued self-supplementation and dietary factors during the trial are possible confounding factors (Boucher 2020).

\section{Prevention vs treatment}

While in vitro and animal studies show potential anticancer effects of $1,25(\mathrm{OH})_{2} \mathrm{D}_{3}$ in $\mathrm{BC}$, human studies (observational and RCTs) often do not show these effects. However, it is important to acknowledge the differences between the two types of studies. Most preclinical studies investigate the effect of treatment with the active $1,25(\mathrm{OH})_{2} \mathrm{D}_{3}$ compound either in vitro in $\mathrm{BC}$ cell lines or in animal models with existing BC, which enables to study the therapeutic effect of vitamin $\mathrm{D}_{3}$ treatment. In addition, animal studies are performed in a homogenous population under uniform conditions such as cancer type, vitamin $\mathrm{D}_{3}$ status, age of the mice. Moreover, only short time effects are studied in animal experiments due to limited follow-up time. While in human studies, the prevention effects of vitamin $D_{3}$ supplementation are studied by patient's follow-up and evaluation of their $\mathrm{BC}$ development during a long follow-up period. Furthermore, in animal models, high doses of the active form of vitamin $\mathrm{D}_{3}, 1,25(\mathrm{OH})_{2} \mathrm{D}_{3}$, are often used, while this is not possible in human studies due to calcaemic side effects and therefore the dose of active $1,25(\mathrm{OH})_{2} \mathrm{D}_{3}$, which is targeting the cancer cells and tumour microenvironment is different in animal vs human studies. Importantly, cell culture studies do not encompass the complex cell-cell interactions which may influence the anti-neoplastic effects of $1,25(\mathrm{OH})_{2} \mathrm{D}_{3}$. For example, adipocytes in breast tissue express CYP27B1, which enables local regulation of $1,25(\mathrm{OH})_{2} \mathrm{D}_{3}$ synthesis. These autocrine and paracrine effects are important to consider as also CYP24A1 and CYP27B1 are expressed in both normal and cancerous breast tissue.

\section{General conclusions}

Numerous preclinical studies illustrated the anti-neoplastic effects of $1,25(\mathrm{OH})_{2} \mathrm{D}_{3}$ or its less calcaemic structural analogues on cell proliferation, apoptosis, autophagy and inflammation in BC. In addition, $1,25(\mathrm{OH})_{2} \mathrm{D}_{3}$ influences cellular processes such as CSCs, EMT and cell metabolism, thereby hampering $\mathrm{BC}$ progression. Indeed $1,25(\mathrm{OH})_{2} \mathrm{D}_{3}$ induced downregulation of $\mathrm{CD} 44$ and mammosphere formation capacities results in a decreased formation of breast CSCs. Also, upregulation of epithelial markers and downregulation of mesenchymal markers after $1,25(\mathrm{OH})_{2} \mathrm{D}_{3}$ treatment inhibits the EMT process. Furthermore, $1,25(\mathrm{OH})_{2} \mathrm{D}_{3}$ affected the PPP pathway and ROS levels in $\mathrm{BC}$ cells. These in vitro and in vivo analyses illustrate the importance of VDR expression on the progression of $\mathrm{BC}$ and the possible anti-tumour applications for $1,25(\mathrm{OH})_{2} \mathrm{D}_{3}$ or analogues in $\mathrm{BC}$ treatment. However, both observational studies and RCTs in humans do not support a protective role of vitamin $\mathrm{D}_{3}$ on $\mathrm{BC}$ risk and development.

Although a possible application for vitamin $\mathrm{D}_{3}$ in the field of $\mathrm{BC}$ could be by the use of vitamin $\mathrm{D}_{3}$ analogues in combination with existing cancer therapies such as chemotherapy or small molecules. Nevertheless, more research is required to prove the effectiveness of vitamin $\mathrm{D}_{3}$ analogues in combination therapies to treat different $\mathrm{BC}$ subtypes. Although, in vitro and in vivo studies describe promising results for the use of $1,25(\mathrm{OH})_{2} \mathrm{D}_{3}$ or analogues to decrease $\mathrm{BC}$ growth and progression, the translation to humans still needs to be further investigated.

\section{Declaration of interest}

The authors declare that there is no conflict of interest that could be perceived as prejudicing the impartiality of this review.

\section{Funding}

J Vanhevel receives a PhD fellowship Fundamental Research from Flanders Research Foundation (FWO 11C2921N). H Wildiers is senior clinical investigator of the Fund for Scientific Research (FWO-Vlaanderen). A Verstuyf receives funding from the University of Leuven (C16/18/006) and Flanders Research Foundation (FWO G.0D01.20N, G0D4217N).
(C) 2022 Society for Endocrinology Published by Bioscientifica Ltd. Printed in Great Britain 


\section{References}

Abdel-Mohsen MA, Abo Deif SM \& Abou-Shamaa LA 2019 IL-6 impairs the activity of vitamin D3 in the regulation of epithelial-mesenchymal transition in triple negative breast cancer. Asian Pacific Journal of Cancer Prevention 20 2267-2273. (https://doi.org/10.31557/ APJCP.2019.20.8.2267)

Abe-Hashimoto J, Kikuchi T, Matsumoto T, Nishii Y, Ogata E \& Ikeda K 1993 Antitumor effect of 22-oxa-calcitriol, a noncalcemic analog of calcitriol, in athymic mice implanted with human breast-carcinoma and its synergism with tamoxifen. Cancer Research 53 2534-2537.

Abu El Maaty MA \& Wolfl S 2017 Vitamin D as a novel regulator of tumor metabolism: insights on potential mechanisms and implications for anti-cancer therapy. International Journal of Molecular Sciences 182184. (https://doi.org/10.3390/ijms18102184)

Abu El Maaty MA, Dabiri Y, Almouhanna F, Blagojevic B, Theobald J, Buttner M \& Wolfl S 2018 Activation of pro-survival metabolic networks by $1,25(\mathrm{OH}) 2 \mathrm{D} 3$ does not hamper the sensitivity of breast cancer cells to chemotherapeutics. Cancer and Metabolism 611. (https://doi.org/10.1186/s40170-018-0183-6)

Al-Azhri J, Zhang Y, Bshara W, Zirpoli G, McCann SE, Khoury T, Morrison CD, Edge SB, Ambrosone CB \& Yao S 2017 Tumor expression of vitamin $\mathrm{D}$ receptor and breast cancer histopathological characteristics and prognosis. Clinical Cancer Research 23 97-103. (https://doi.org/10.1158/1078-0432.CCR-16-0075)

Albertson DG, Ylstra B, Segraves R, Collins C, Dairkee SH, Kowbel D, Kuo WL, Gray JW \& Pinkel D 2000 Quantitative mapping of amplicon structure by array CGH identifies CYP24 as a candidate oncogene. Nature Genetics 25 144-146. (https://doi.org/10.1038/75985)

Al-Hajj M, Wicha MS, Benito-Hernandez A, Morrison SJ \& Clarke MF 2003 Prospective identification of tumorigenic breast cancer cells. PNAS $\mathbf{1 0 0}$ 3983-3988. (https://doi.org/10.1073/pnas.0530291100)

Anisiewicz A, Pawlik A, Filip-Psurska B, Turlej E, Dzimira S, Milczarek M, Gdesz K, Papiernik D, Jarosz J, Klopotowska D, et al. 2018 Unfavorable effect of calcitriol and its low-calcemic analogs on metastasis of 4T1 mouse mammary gland cancer. International Journal of Oncology $\mathbf{5 2}$ 103-126. (https://doi.org/10.3892/ijo.2017.4185)

Anisiewicz A, Filip-Psurska B, Pawlik A, Nasulewicz-Goldeman A, Piasecki T, Kowalski K, Maciejewska M, Jarosz J, Banach J, Papiernik D, et al. 2019 Calcitriol analogues decrease lung metastasis but impair bone metabolism in aged ovariectomized mice bearing 4T1 mammary gland tumours. Aging and Disease 10 977-991. (https://doi. org/10.14336/AD.2018.0921)

Anisiewicz A, Kowalski K, Banach J, Labedz N, Stachowicz-Suhs M, Piotrowska A, Milczarek M, Klopotowska D, Dziegiel P \& Wietrzyk J 2020 Vitamin D metabolite profile in cholecalciferol- or calcitriolsupplemented healthy and mammary gland tumor-bearing mice. Nutrients 12 3416. (https://doi.org/10.3390/nu12113416)

Arnaout A, Robertson S, Pond GR, Vieth R, Jeong A, Hilton J, Ramsey T \& Clemons M 2019 Randomized window of opportunity trial evaluating high-dose vitamin D in breast cancer patients. Breast Cancer Research and Treatment 178 347-356. (https://doi.org/10.1007/s10549-019-05392-9)

Attia YM, El-Kersh DM, Ammar RA, Adel A, Khalil A, Walid H, Eskander K, Hamdy M, Reda N, Mohsen NE, et al. 2020 Inhibition of aldehyde dehydrogenase-1 and p-glycoprotein-mediated multidrug resistance by curcumin and vitamin D3 increases sensitivity to paclitaxel in breast cancer. Chemico-Biological Interactions 315 108865. (https://doi. org/10.1016/j.cbi.2019.108865)

Beaudin SG, Robilotto S \& Welsh J 2015 Comparative regulation of gene expression by 1,25-dihydroxyvitamin D3 in cells derived from normal mammary tissue and breast cancer. Journal of Steroid Biochemistry and Molecular Biology 148 96-102. (https://doi.org/10.1016/j. jsbmb.2014.09.014)

Beaudin S \& Welsh J 2017 1,25-Dihydroxyvitamin D regulation of glutamine synthetase and glutamine metabolism in human mammary epithelial cells. Endocrinology 158 4174-4188. (https://doi.org/10.1210/ en.2017-00238)

Bilinski K \& Boyages J 2013 Association between 25-hydroxyvitamin D concentration and breast cancer risk in an Australian population: an observational case-control study. Breast Cancer Research and Treatment 137 599-607. (https://doi.org/10.1007/s10549-012-2381-1)

Bonnet D \& Dick JE 1997 Human acute myeloid leukemia is organized as a hierarchy that originates from a primitive hematopoietic cell. Nature Medicine 3 730-737. (https://doi.org/10.1038/nm0797-730)

Boucher BJ 2020 Why do so many trials of vitamin D supplementation fail? Endocrine Connections 9 R195-R206. (https://doi.org/10.1530/EC-20-0274)

Bouillon R, Marcocci C, Carmeliet G, Bikle D, White JH, DawsonHughes B, Lips P, Munns CF, Lazaretti-Castro M, Giustina A, et al. 2019 Skeletal and extraskeletal actions of vitamin D: current evidence and outstanding questions. Endocrine Reviews 40 1109-1151. (https://doi. org/10.1210/er.2018-00126)

Cai H, Jiao Y, Li Y, Yang Z, He M \& Liu Y 2019 Low CYP24A1 mRNA expression and its role in prognosis of breast cancer. Scientific Reports 9 13714. (https://doi.org/10.1038/s41598-019-50214-z)

Campos LT, Brentani H, Roela RA, Katayama ML, Lima L, Rolim CF, Milani C, Folgueira MA \& Brentani MM 2013 Differences in transcriptional effects of 1alpha, 25 dihydroxyvitamin D3 on fibroblasts associated to breast carcinomas and from paired normal breast tissues. Journal of Steroid Biochemistry and Molecular Biology 133 12-24. (https://doi.org/10.1016/j.jsbmb.2012.08.002)

Cao Y, Du Y, Liu F, Feng Y, Cheng S, Guan S, Wang Y, Li X, Li B, Jin F, et al. 2018 Vitamin D aggravates breast cancer by inducing immunosuppression in the tumor bearing mouse. Immunotherapy $\mathbf{1 0}$ 555-566. (https://doi.org/10.2217/imt-2017-0131)

Chandler PD, Chen WY, Ajala ON, Hazra A, Cook N, Bubes V, Lee IM, Giovannucci EL, Willett W, Buring JE, et al. 2020 Effect of vitamin D3 supplements on development of advanced cancer: a secondary analysis of the VITAL randomized clinical trial. JAMA Network Open 3 e2025850. (https://doi.org/10.1001/jamanetworkopen.2020.25850)

Chen L, Yang R, Qiao W, Yuan X, Wang S, Goltzman D \& Miao D 2018a 1,25-Dihydroxy vitamin $\mathrm{D}$ prevents tumorigenesis by inhibiting oxidative stress and inducing tumor cellular senescence in mice. International Journal of Cancer 143 368-382. (https://doi.org/10.1002/ijc.31317)

Chen W, Hoffmann AD, Liu H \& Liu X 2018b Organotropism: new insights into molecular mechanisms of breast cancer metastasis. NPJ Precision Oncology 2 4. (https://doi.org/10.1038/s41698-018-0047-0)

Christakos S, Dhawan P, Verstuyf A, Verlinden L \& Carmeliet G 2016 Vitamin D: metabolism, molecular mechanism of action, and pleiotropic effects. Physiological Reviews 96 365-408. (https://doi. org/10.1152/physrev.00014.2015)

Christakos S, Li S, De La Cruz J \& Bikle DD 2019 New developments in our understanding of vitamin metabolism, action and treatment. Metabolism: Clinical and Experimental 98 112-120. (https://doi. org/10.1016/j.metabol.2019.06.010)

Crew KD, Anderson GL, Hershman DL, Terry MB, Tehranifar P, Lew DL, Yee M, Brown EA, Kairouz SS, Kuwajerwala N, et al. 2019 Randomized double-blind placebo-controlled biomarker modulation study of vitamin D supplementation in premenopausal women at high risk for breast cancer (SWOG S0812). Cancer Prevention Research 12 481-490. (https://doi.org/10.1158/1940-6207.CAPR-18-0444)

Dhawan P, Weider R \& Christakos S 2009 CCAAT enhancer-binding protein alpha is a molecular target of 1,25-dihydroxyvitamin D3 in MCF-7 breast cancer cells. Journal of Biological Chemistry 284 3086-3095. (https://doi.org/10.1074/jbc.M803602200)

Duffy MJ, Murray A, Synnott NC, O’Donovan N \& Crown J 2017 Vitamin $\mathrm{D}$ analogues: potential use in cancer treatment. Critical Reviews in Oncology/Hematology 112 190-197. (https://doi.org/10.1016/j. critrevonc.2017.02.015)

Duffy MJ, Synnott NC \& Crown J 2018 Mutant p53 in breast cancer: potential as a therapeutic target and biomarker. Breast Cancer Research and Treatment 170 213-219. (https://doi.org/10.1007/s10549-018-4753-7) https://erc.bioscientifica.com

https://doi.org/10.1530/ERC-21-0182 (c) 2022 Society for Endocrinology Published by Bioscientifica Ltd. Printed in Great Britain 
Estebanez N, Gomez-Acebo I, Palazuelos C, Llorca J \& Dierssen-Sotos T 2018 Vitamin D exposure and risk of breast cancer: a meta-analysis. Scientific Reports 8 9039. (https://doi.org/10.1038/s41598-018-27297-1)

Fedchenko N \& Reifenrath J 2014 Different approaches for interpretation and reporting of immunohistochemistry analysis results in the bone tissue - a review. Diagnostic Pathology 9 221. (https://doi.org/10.1186/ s13000-014-0221-9)

Feldman D, Krishnan AV, Swami S, Giovannucci E \& Feldman BJ 2014 The role of vitamin D in reducing cancer risk and progression. Nature Reviews: Cancer 14 342-357. (https://doi.org/10.1038/nrc3691)

Fernandez-Barral A, Bustamante-Madrid P, Ferrer-Mayorga G, Barbachano A, Larriba MJ \& Munoz A 2020 Vitamin D effects on cell differentiation and stemness in cancer. Cancers 12 2413. (https://doi. org/10.3390/cancers12092413)

Fonseca-Filho VCN, Katayama MLH, Lyra EC, Maria DA, Basso RA, Nonogaki S, Guerra JM, Maistro S, Goes JCGS \& Folgueira MAAK 2017 Orthotopic tumorgrafts in nude mice as a model to evaluate calcitriol effects in breast cancer. Brazilian Journal of Biology 77 856-867. (https://doi.org/10.1590/1519-6984.04016)

Friedrich M, Reichert K, Woeste A, Polack S, Fischer D, Hoellen F, Rody A, Koster F \& Thill M 2018 Effects of combined treatment with vitamin D and COX2 inhibitors on breast cancer cell lines. Anticancer Research 38 1201-1207. (https://doi.org/10.21873/anticanres.12340)

Gao ZH, Li CX, Liu M \& Jiang JY 2020 Predictive and prognostic role of tumour-infiltrating lymphocytes in breast cancer patients with different molecular subtypes: a meta-analysis. BMC Cancer 201150. (https://doi.org/10.1186/s12885-020-07654-y)

Garcia-Quiroz J, Garcia-Becerra R, Santos-Martinez N, Avila E, Larrea F \& Diaz L 2016 Calcitriol stimulates gene expression of cathelicidin antimicrobial peptide in breast cancer cells with different phenotype. Journal of Biomedical Science 23 78. (https://doi.org/10.1186/s12929016-0298-4)

Garcia-Quiroz J, Garcia-Becerra R, Santos-Cuevas C, Ramirez-Nava GJ, Morales-Guadarrama G, Cardenas-Ochoa N, Segovia-Mendoza M, Prado-Garcia H, Ordaz-Rosado D, Avila E, et al. 2019 Synergistic antitumorigenic activity of calcitriol with curcumin or resveratrol is mediated by angiogenesis inhibition in triple negative breast cancer xenografts. Cancers 11 1739. (https://doi.org/10.3390/cancers11111739)

Garland FC, Garland CF, Gorham ED \& Young JF 1990 Geographic variation in breast cancer mortality in the United States: a hypothesis involving exposure to solar radiation. Preventive Medicine 19 614-622. (https://doi.org/10.1016/0091-7435(90)90058-r)

Garland CF, Garland FC, Gorham ED, Lipkin M, Newmark H, Mohr SB \& Holick MF 2006 The role of vitamin D in cancer prevention. American Journal of Public Health 96 252-261. (https://doi.org/10.2105/ AJPH.2004.045260)

Heublein S, Mayr D, Meindl A, Kircher A, Jeschke U \& Ditsch N 2017 Vitamin D receptor, retinoid $X$ receptor and peroxisome proliferatoractivated receptor gamma are overexpressed in BRCA1 mutated breast cancer and predict prognosis. Journal of Experimental and Clinical Cancer Research 36 57. (https://doi.org/10.1186/s13046-017-0517-1)

Horas K, Zheng Y, Fong-Yee C, Macfarlane E, Manibo J, Chen Y, Qiao J, Gao M, Haydar N, McDonald MM, et al. 2019 Loss of the vitamin D receptor in human breast cancer cells promotes epithelial to mesenchymal cell transition and skeletal colonization. Journal of Bone and Mineral Research 34 1721-1732. (https://doi.org/10.1002/ jbmr.3744)

Hossain S, Beydoun MA, Beydoun HA, Chen X, Zonderman AB \& Wood RJ 2019 Vitamin D and breast cancer: a systematic review and metaanalysis of observational studies. Clinical Nutrition ESPEN 30 170-184. (https://doi.org/10.1016/j.clnesp.2018.12.085)

Hoyer-Hansen M, Bastholm L, Szyniarowski P, Campanella M, Szabadkai G, Farkas T, Bianchi K, Fehrenbacher N, Elling F, Rizzuto R, et al. 2007 Control of macroautophagy by calcium, calmodulindependent kinase kinase-beta, and Bcl-2. Molecular Cell 25 193-205. (https://doi.org/10.1016/j.molcel.2006.12.009)
Hummel DM, Fetahu IS, Groschel C, Manhardt T \& Kallay E 2014 Role of proinflammatory cytokines on expression of vitamin D metabolism and target genes in colon cancer cells. Journal of Steroid Biochemistry and Molecular Biology 144 91-95. (https://doi.org/10.1016/j.jsbmb.2013.09.017)

Huss L, Butt ST, Borgquist S, Elebro K, Sandsveden M, Rosendahl A \& Manjer J 2019 Vitamin D receptor expression in invasive breast tumors and breast cancer survival. Breast Cancer Research 21 84. (https://doi. org/10.1186/s13058-019-1169-1)

Jaggupilli A \& Elkord E 2012 Significance of CD44 and CD24 as cancer stem cell markers: an enduring ambiguity. Clinical and Developmental Immunology 2012 708036. (https://doi.org/10.1155/2012/708036)

Jang M, Kim SS \& Lee J 2013 Cancer cell metabolism: implications for therapeutic targets. Experimental and Molecular Medicine 45 e45. (https://doi.org/10.1038/emm.2013.85)

Jensen SS, Madsen MW, Lukas J, Binderup L \& Bartek J 2001 Inhibitory effects of 1alpha,25-dihydroxyvitamin $\mathrm{D}(3)$ on the $\mathrm{G}(1)$-S phasecontrolling machinery. Molecular Endocrinology 15 1370-1380. (https:// doi.org/10.1210/mend.15.8.0673)

Jeon SM \& Shin EA 2018 Exploring vitamin D metabolism and function in cancer. Experimental and Molecular Medicine 50 1-14. (https://doi. org/10.1038/s12276-018-0038-9)

Jeong Y, Swami S, Krishnan AV, Williams JD, Martin S, Horst RL, Albertelli MA, Feldman BJ, Feldman D \& Diehn M 2015 Inhibition of mouse breast tumor-initiating cells by calcitriol and dietary vitamin D. Molecular Cancer Therapeutics 14 1951-1961. (https://doi. org/10.1158/1535-7163.MCT-15-0066)

Jiang X, O'Reilly PF, Aschard H, Hsu YH, Richards JB, Dupuis J, Ingelsson E, Karasik D, Pilz S, Berry D, et al. 2018 Genome-wide association study in 79,366 European-ancestry individuals informs the genetic architecture of 25 -hydroxyvitamin D levels. Nature Communications 9 260. (https://doi.org/10.1038/s41467-017-02662-2)

Jiang X, Dimou NL, Al-Dabhani K, Lewis SJ, Martin RM, Haycock PC, Gunter MJ, Key TJ, Eeles RA, Muir K, et al. 2019 Circulating vitamin D concentrations and risk of breast and prostate cancer: a Mendelian randomization study. International Journal of Epidemiology $\mathbf{4 8}$ 1416-1424. (https://doi.org/10.1093/ije/dyy284)

Jiang X, Ge T \& Chen CY 2021 The causal role of circulating vitamin D concentrations in human complex traits and diseases: a large-scale Mendelian randomization study. Scientific Reports 11 184. (https://doi. org/10.1038/s41598-020-80655-w)

Johnson KS, Conant EF \& Soo MS 2021 Molecular subtypes of breast cancer: a review for breast radiologists. Journal of Breast Imaging 3 12-24. (https://doi.org/10.1093/jbi/wbaa110)

Karkeni E, Morin SO, Bou Tayeh B, Goubard A, Josselin E, Castellano R, Fauriat C, Guittard G, Olive D \& Nunes JA 2019 Vitamin D controls tumor growth and CD8+ T cell infiltration in breast cancer. Frontiers in Immunology 10 1307. (https://doi.org/10.3389/fimmu.2019.01307)

Karthikayan A, Sureshkumar S, Kadambari D \& Vijayakumar C 2018 Low serum 25-hydroxy vitamin D levels are associated with aggressive breast cancer variants and poor prognostic factors in patients with breast carcinoma. Archives of Endocrinology and Metabolism 62 452-459. (https://doi.org/10.20945/2359-3997000000062)

Klopotowska D, Matuszyk J \& Wietrzyk J 2019 Steroid hormone calcitriol and its analog tacalcitol inhibit miR-125b expression in a human breast cancer MCF-7 cell line. Steroids 141 70-75. (https://doi. org/10.1016/j.steroids.2018.11.014)

Krishnan AV, Swami S, Peng L, Wang J, Moreno J \& Feldman D 2010 Tissue-selective regulation of aromatase expression by calcitriol: implications for breast cancer therapy. Endocrinology 151 32-42. (https://doi.org/10.1210/en.2009-0855)

Kristiansen G, Winzer KJ, Mayordomo E, Bellach J, Schluns K, Denkert C, Dahl E, Pilarsky C, Altevogt P, Guski H, et al. 2003 CD24 expression is a new prognostic marker in breast cancer. Clinical Cancer Research $\mathbf{9}$ 4906-4913.

Kurozumi S, Matsumoto H, Kurosumi M, Inoue K, Fujii T, Horiguchi J, Shirabe K, Oyama T \& Kuwano H 2019 Prognostic significance of 
tumour-infiltrating lymphocytes for oestrogen receptor-negative breast cancer without lymph node metastasis. Oncology Letters 17 2647-2656. (https://doi.org/10.3892/ol.2019.9938)

LaPorta E \& Welsh J 2014 Modeling vitamin D actions in triple negative/ basal-like breast cancer. Journal of Steroid Biochemistry and Molecular Biology 144 65-73. (https://doi.org/10.1016/j.jsbmb.2013.10.022)

Lappe J, Watson P, Travers-Gustafson D, Recker R, Garland C, Gorham E, Baggerly K \& McDonnell SL 2017 Effect of vitamin D and calcium supplementation on cancer incidence in older women: a randomized clinical trial. JAMA 317 1234-1243. (https://doi.org/10.1001/ jama.2017.2115)

Larriba MJ, Garcia de Herreros A \& Munoz A 2016 Vitamin D and the epithelial to mesenchymal transition. Stem Cells International 2016 6213872. (https://doi.org/10.1155/2016/6213872)

Le Naour A, Koffi Y, Diab M, Le Guennec D, Rouge S, Aldekwer S, Goncalves-Mendes N, Talvas J, Farges MC, Caldefie-Chezet F, et al. 2020 EO771, the first luminal B mammary cancer cell line from C57BL/6 mice. Cancer Cell International 20 328. (https://doi. org/10.1186/s12935-020-01418-1)

Lemon BD \& Freedman LP 1996 Selective effects of ligands on vitamin D3 receptor- and retinoid $\mathrm{X}$ receptor-mediated gene activation in vivo. Molecular and Cellular Biology 16 1006-1016. (https://doi.org/10.1128/ MCB.16.3.1006)

Leyssens C, Verlinden L \& Verstuyf A 2013 Antineoplastic effects of $1,25(\mathrm{OH}) 2 \mathrm{D} 3$ and its analogs in breast, prostate and colorectal cancer. Endocrine-Related Cancer 20 R31-R47. (https://doi.org/10.1530/ERC-120381)

Leyssens C, Verlinden L \& Verstuyf A 2014 The future of vitamin D analogs. Frontiers in Physiology 5 122. (https://doi.org/10.3389/ fphys.2014.00122)

Li J, Luco AL, Camirand A, St-Arnaud R \& Kremer R 2021a Vitamin D regulates CXCL12/CXCR4 and epithelial-to-mesenchymal transition in a model of breast cancer metastasis to lung. Endocrinology 162 bqab049. (https://doi.org/10.1210/endocr/bqab049)

Li Z, Wu L, Zhang J, Huang X, Thabane L \& Li G $2021 b$ Effect of vitamin D supplementation on risk of breast cancer: a systematic review and meta-analysis of randomized controlled trials. Frontiers in Nutrition $\mathbf{8}$ 655727. (https://doi.org/10.3389/fnut.2021.655727)

Lim ST, Jeon YW, Gwak H, Kim SY \& Suh YJ 2018 Synergistic anticancer effects of ruxolitinib and calcitriol in estrogen receptorpositive, human epidermal growth factor receptor 2positive breast cancer cells. Molecular Medicine Reports 17 5581-5588. (https://doi.org/10.3892/ mmr.2018.8580)

Liu X, Bi L, Wang Q, Wen M, Li C, Ren Y, Jiao Q, Mao JH, Wang C, Wei G, et al. 2018 miR-1204 targets VDR to promotes epithelial-mesenchymal transition and metastasis in breast cancer. Oncogene 37 3426-3439. (https://doi.org/10.1038/s41388-018-0215-2)

Lopes N, Sousa B, Martins D, Gomes M, Vieira D, Veronese LA, Milanezi F, Paredes J, Costa JL \& Schmitt F 2010 Alterations in vitamin D signalling and metabolic pathways in breast cancer progression: a study of VDR, CYP27B1 and CYP24A1 expression in benign and malignant breast lesions. BMC Cancer 10 483. (https://doi. org/10.1186/1471-2407-10-483)

Lopes N, Carvalho J, Duraes C, Sousa B, Gomes M, Costa JL, Oliveira C, Paredes J \& Schmitt F 2012a 1Alpha,25-dihydroxyvitamin D3 induces de novo E-cadherin expression in triple-negative breast cancer cells by CDH1-promoter demethylation. Anticancer Research 32 249-257.

Lopes N, Paredes J, Costa JL, Ylstra B \& Schmitt F 2012b Vitamin D and the mammary gland: a review on its role in normal development and breast cancer. Breast Cancer Research 14 211. (https://doi.org/10.1186/ bcr3178)

Machado MRM, de Sousa Almeida-Filho B, De Luca Vespoli H, Schmitt EB, Nahas-Neto J \& Nahas EAP 2019 Low pretreatment serum concentration of vitamin $\mathrm{D}$ at breast cancer diagnosis in postmenopausal women. Menopause 26 293-299. (https://doi. org/10.1097/GME.0000000000001203)
Mahmoud S, Lee A, Ellis I \& Green A 2012 CD8(+) T lymphocytes infiltrating breast cancer: A promising new prognostic marker? Oncoimmunology 1 364-365. (https://doi.org/10.4161/onci.18614)

Manson JE, Cook NR, Lee IM, Christen W, Bassuk SS, Mora S, Gibson H, Gordon D, Copeland T, D'Agostino D, et al. 2019 Vitamin D supplements and prevention of cancer and cardiovascular disease. New England Journal of Medicine 380 33-44. (https://doi.org/10.1056/ NEJMoa1809944)

Martinez-Lostao L, Anel A \& Pardo J 2015 How do cytotoxic lymphocytes kill cancer cells? Clinical Cancer Research 21 5047-5056. (https://doi. org/10.1158/1078-0432.CCR-15-0685)

Martinez-Reza I, Diaz L, Barrera D, Segovia-Mendoza M, PedrazaSanchez S, Soca-Chafre G, Larrea F \& Garcia-Becerra R 2019 Calcitriol inhibits the proliferation of triple-negative breast cancer cells through a mechanism involving the proinflammatory cytokines IL-1beta and TNF-alpha. Journal of Immunology Research 2019 6384278. (https://doi. org/10.1155/2019/6384278)

Matthews DG, D’Angelo J, Drelich J \& Welsh J 2016 Adipose-specific Vdr deletion alters body fat and enhances mammary epithelial density. Journal of Steroid Biochemistry and Molecular Biology 164 299-308. (https://doi.org/10.1016/j.jsbmb.2015.09.035)

Mattiuzzi C \& Lippi G 2019 Current cancer epidemiology. Journal of Epidemiology and Global Health 9 217-222. (https://doi.org/10.2991/ jegh.k.191008.001)

Mittal MK, Myers JN, Misra S, Bailey CK \& Chaudhuri G 2008 In vivo binding to and functional repression of the VDR gene promoter by SLUG in human breast cells. Biochemical and Biophysical Research Communications 372 30-34. (https://doi.org/10.1016/j.bbrc.2008.04.187)

Mueller C, Haymond A, Davis JB, Williams A \& Espina V 2018 Protein biomarkers for subtyping breast cancer and implications for future research. Expert Review of Proteomics 15 131-152. (https://doi.org/10.10 80/14789450.2018.1421071)

Murray A, Madden SF, Synnott NC, Klinger R, O'Connor D, O'Donovan N, Gallagher W, Crown J \& Duffy MJ 2017 Vitamin D receptor as a target for breast cancer therapy. Endocrine-Related Cancer 24 181-195. (https://doi.org/10.1530/ERC-16-0463)

Oshi M, Asaoka M, Tokumaru Y, Yan L, Matsuyama R, Ishikawa T, Endo I \& Takabe K 2020 CD8 T cell score as a prognostic biomarker for triple negative breast cancer. International Journal of Molecular Sciences $\mathbf{2 1}$ 6968. (https://doi.org/10.3390/ijms21186968)

Pawlik A, Anisiewicz A, Filip-Psurska B, Nowak M, Turlej E, Trynda J, Banach J, Gretkierewicz P \& Wietrzyk J 2018 Calcitriol and its analogs establish the immunosuppressive microenvironment that drives metastasis in $4 \mathrm{~T} 1$ mouse mammary gland cancer. International Journal of Molecular Sciences 19 2116. (https://doi.org/10.3390/ijms19072116)

Peehl DM \& Feldman D 2004 Interaction of nuclear receptor ligands with the vitamin D signaling pathway in prostate cancer. Journal of Steroid Biochemistry and Molecular Biology 92 307-315. (https://doi. org/10.1016/j.jsbmb.2004.10.006)

Peppone LJ, Huston AJ, Reid ME, Rosier RN, Zakharia Y, Trump DL, Mustian KM, Janelsins MC, Purnell JQ \& Morrow GR 2011 The effect of various vitamin D supplementation regimens in breast cancer patients. Breast Cancer Research and Treatment 127 171-177. (https:// doi.org/10.1007/s10549-011-1415-4)

Peppone LJ, Rickles AS, Janelsins MC, Insalaco MR \& Skinner KA 2012 The association between breast cancer prognostic indicators and serum 25-OH vitamin D levels. Annals of Surgical Oncology 19 2590-2599. (https://doi.org/10.1245/s10434-012-2297-3)

Phannasil P, Ansari IH, El Azzouny M, Longacre MJ, Rattanapornsompong K, Burant CF, MacDonald MJ \& Jitrapakdee S 2017 Mass spectrometry analysis shows the biosynthetic pathways supported by pyruvate carboxylase in highly invasive breast cancer cells. Biochimica et Biophysica Acta: Molecular Basis of Disease 1863 537-551. (https://doi.org/10.1016/j.bbadis.2016.11.021)

Qin B, Xu B, Ji N, Yao S, Pawlish K, Llanos AAM, Lin Y, Demissie K, Ambrosone CB, Hong CC, et al. 2020 Intake of vitamin D and calcium, 
sun exposure, and risk of breast cancer subtypes among black women. American Journal of Clinical Nutrition 111 396-405. (https://doi. org/10.1093/ajcn/nqz302)

Reichrath J, Reichrath S, Heyne K, Vogt T \& Roemer K 2014 Tumor suppression in skin and other tissues via cross-talk between vitamin D- and p53-signaling. Frontiers in Physiology 5 166. (https://doi. org/10.3389/fphys.2014.00166)

Richards SE, Weierstahl KA \& Kelts JL 2015 Vitamin D effect on growth and vitamin D metabolizing enzymes in triple-negative breast cancer. Anticancer Research 35 805-810.

Rodriguez GC, Turbov J, Rosales R, Yoo J, Hunn J, Zappia KJ, Lund K, Barry CP, Rodriguez IV, Pike JW, et al. 2016 Progestins inhibit calcitriol-induced CYP24A1 and synergistically inhibit ovarian cancer cell viability: an opportunity for chemoprevention. Gynecologic Oncology 143 159-167. (https://doi.org/10.1016/j. ygyno.2016.04.022)

Rossdeutscher L, Li J, Luco AL, Fadhil I, Ochietti B, Camirand A, Huang DC, Reinhardt TA, Muller W \& Kremer R 2015 Chemoprevention activity of 25-hydroxyvitamin D in the MMTVPyMT mouse model of breast cancer. Cancer Prevention Research $\mathbf{8}$ 120-128. (https://doi.org/10.1158/1940-6207.CAPR-14-0110)

Saeg F \& Anbalagan M 2018 Breast cancer stem cells and the challenges of eradication: a review of novel therapies. Stem Cell Investigation 539. (https://doi.org/10.21037/sci.2018.10.05)

Sanchez-Martinez R, Castillo AI, Steinmeyer A \& Aranda A 2006 The retinoid $\mathrm{X}$ receptor ligand restores defective signalling by the vitamin D receptor. EMBO Reports 7 1030-1034. (https://doi.org/10.1038/sj. embor.7400776)

Santos JM \& Hussain F 2019 VD3 mitigates breast cancer aggressiveness by targeting V-H(+)-ATPase. Journal of Nutritional Biochemistry 70 185-193. (https://doi.org/10.1016/j.jnutbio.2019.05.005)

Santos JM, Khan ZS, Munir MT, Tarafdar K, Rahman SM \& Hussain F 2018 Vitamin D3 decreases glycolysis and invasiveness, and increases cellular stiffness in breast cancer cells. Journal of Nutritional Biochemistry 53 111-120. (https://doi.org/10.1016/j.jnutbio.2017.10.013)

Scragg RKR 2019 Overview of results from the vitamin D assessment (ViDA) study. Journal of Endocrinological Investigation 42 1391-1399. (https://doi.org/10.1007/s40618-019-01056-z)

Segovia-Mendoza M, Diaz L, Gonzalez-Gonzalez ME, Martinez-Reza I, Garcia-Quiroz J, Prado-Garcia H, Ibarra-Sanchez MJ, Esparza-Lopez J, Larrea F \& Garcia-Becerra R 2015 Calcitriol and its analogues enhance the antiproliferative activity of gefitinib in breast cancer cells. Journal of Steroid Biochemistry and Molecular Biology 148 122-131. (https://doi. org/10.1016/j.jsbmb.2014.12.006)

Segovia-Mendoza M, Diaz L, Prado-Garcia H, Reginato MJ, Larrea F \& Garcia-Becerra R 2017 The addition of calcitriol or its synthetic analog EB1089 to lapatinib and neratinib treatment inhibits cell growth and promotes apoptosis in breast cancer cells. American Journal of Cancer Research 7 1486-1500.

Senbanjo LT \& Chellaiah MA 2017 CD44: a multifunctional cell surface adhesion receptor is a regulator of progression and metastasis of cancer cells. Frontiers in Cell and Developmental Biology 5 18. (https:// doi.org/10.3389/fcell.2017.00018)

Shan NL, Wahler J, Lee HJ, Bak MJ, Gupta SD, Maehr H \& Suh N 2017 Vitamin D compounds inhibit cancer stem-like cells and induce differentiation in triple negative breast cancer. Journal of Steroid Biochemistry and Molecular Biology 173 122-129. (https://doi. org/10.1016/j.jsbmb.2016.12.001)

Shan NL, Minden A, Furmanski P, Bak MJ, Cai L, Wernyj R, Sargsyan D, Cheng D, Wu R, Kuo HD, et al. 2020 Analysis of the transcriptome: regulation of cancer stemness in breast ductal carcinoma in situ by vitamin D compounds. Cancer Prevention Research 13 673-686. (https://doi.org/10.1158/1940-6207.CAPR-19-0566)

So JY \& Suh N 2015 Targeting cancer stem cells in solid tumors by vitamin D. Journal of Steroid Biochemistry and Molecular Biology 148 79-85. (https://doi.org/10.1016/j.jsbmb.2014.10.007)
So JY, Lee HJ, Smolarek AK, Paul S, Wang CX, Maehr H, Uskokovic M, Zheng X, Conney AH, Cai L, et al. 2011 A novel Gemini vitamin D analog represses the expression of a stem cell marker CD44 in breast cancer. Molecular Pharmacology 79 360-367. (https://doi.org/10.1124/ mol.110.068403)

So JY, Wahler J, Das Gupta S, Salerno DM, Maehr H, Uskokovic M \& Suh N 2015 HES1-mediated inhibition of Notch1 signaling by a Gemini vitamin D analog leads to decreased CD44(+)/CD24(-/low) tumorinitiating subpopulation in basal-like breast cancer. Journal of Steroid Biochemistry and Molecular Biology 148 111-121. (https://doi. org/10.1016/j.jsbmb.2014.12.013)

Song K \& Farzaneh M 2021 Signaling pathways governing breast cancer stem cells behavior. Stem Cell Research and Therapy 12 245. (https://doi. org/10.1186/s13287-021-02321-w)

Song D, Deng Y, Liu K, Zhou L, Li N, Zheng Y, Hao Q, Yang S, Wu Y, Zhai Z, et al. 2019 Vitamin D intake, blood vitamin D levels, and the risk of breast cancer: a dose-response meta-analysis of observational studies. Aging 11 12708-12732. (https://doi.org/10.18632/aging.102597)

Spiro A \& Buttriss JL 2014 Vitamin D: an overview of vitamin D status and intake in Europe. Nutrition Bulletin 39 322-350. (https://doi. org/10.1111/nbu.12108)

Stambolsky P, Tabach Y, Fontemaggi G, Weisz L, Maor-Aloni R, Siegfried Z, Shiff I, Kogan I, Shay M, Kalo E, et al. 2010 Modulation of the vitamin D3 response by cancer-associated mutant p53. Cancer Cell 17 273-285. (https://doi.org/10.1016/j.ccr.2009.11.025)

Stanton SE \& Disis ML 2016 Clinical significance of tumor-infiltrating lymphocytes in breast cancer. Journal for ImmunoTherapy of Cancer 4 59. (https://doi.org/10.1186/s40425-016-0165-6)

Sullivan NJ, Sasser AK, Axel AE, Vesuna F, Raman V, Ramirez N, Oberyszyn TM \& Hall BM 2009 Interleukin-6 induces an epithelialmesenchymal transition phenotype in human breast cancer cells. Oncogene 28 2940-2947. (https://doi.org/10.1038/onc.2009.180)

Sundaram S, Sea A, Feldman S, Strawbridge R, Hoopes PJ, Demidenko E, Binderup L \& Gewirtz DA 2003 The combination of a potent vitamin D3 analog, EB 1089, with ionizing radiation reduces tumor growth and induces apoptosis of MCF-7 breast tumor xenografts in nude mice. Clinical Cancer Research 9 2350-2356.

Sung H, Ferlay J, Siegel RL, Laversanne M, Soerjomataram I, Jemal A \& Bray F 2021 Global cancer statistics 2020: GLOBOCAN estimates of incidence and mortality worldwide for 36 cancers in 185 countries. CA: A Cancer Journal for Clinicians 71 209-249. (https://doi. org/10.3322/caac.21660)

Swami S, Krishnan AV \& Feldman D 2000 1alpha,25-Dihydroxyvitamin D3 down-regulates estrogen receptor abundance and suppresses estrogen actions in MCF-7 human breast cancer cells. Clinical Cancer Research 6 3371-3379.

Swami S, Krishnan AV, Wang JY, Jensen K, Peng L, Albertelli MA \& Feldman D 2011 Inhibitory effects of calcitriol on the growth of MCF-7 breast cancer xenografts in nude mice: selective modulation of aromatase expression in vivo. Hormones and Cancer 2 190-202. (https://doi.org/10.1007/s12672-011-0073-7)

Tavera-Mendoza LE, Westerling T, Libby E, Marusyk A, Cato L, Cassani R, Cameron LA, Ficarro SB, Marto JA, Klawitter J, et al. 2017 Vitamin D receptor regulates autophagy in the normal mammary gland and in luminal breast cancer cells. PNAS 114 E2186-E2194. (https://doi. org/10.1073/pnas.1615015114)

Thakkar A, Wang B, Picon-Ruiz M, Buchwald P \& Ince TA 2016 Vitamin D and androgen receptor-targeted therapy for triple-negative breast cancer. Breast Cancer Research and Treatment 157 77-90. (https://doi. org/10.1007/s10549-016-3807-y)

Townsend K, Banwell CM, Guy M, Colston KW, Mansi JL, Stewart PM, Campbell MJ \& Hewison M 2005 Autocrine metabolism of vitamin D in normal and malignant breast tissue. Clinical Cancer Research $\mathbf{1 1}$ 3579-3586. (https://doi.org/10.1158/1078-0432.CCR-04-2359)

Vanoirbeek E, Krishnan A, Eelen G, Verlinden L, Bouillon R, Feldman D \& Verstuyf A 2011 The anti-cancer and anti-inflammatory actions of https://erc bioscientifica com

https://doi.org/10.1530/ERC-21-0182 (c) 2022 Society for Endocrinology Published by Bioscientifica Ltd. Printed in Great Britain 
1,25(OH)(2)D(3). Best Practice and Research: Clinical Endocrinology and Metabolism 25 593-604. (https://doi.org/10.1016/j.beem.2011.05.001)

Vaughan-Shaw PG, O'Sullivan F, Farrington SM, Theodoratou E, Campbell H, Dunlop MG \& Zgaga L 2017 The impact of vitamin D pathway genetic variation and circulating 25-hydroxyvitamin $\mathrm{D}$ on cancer outcome: systematic review and meta-analysis. British Journal of Cancer 116 1092-1110. (https://doi.org/10.1038/bjc.2017.44)

Verlinden L, Verstuyf A, Convents R, Marcelis S, Van Camp M \& Bouillon R 1998 Action of 1,25(OH)2D3 on the cell cycle genes, cyclin D1, p21 and p27 in MCF-7 cells. Molecular and Cellular Endocrinology 142 57-65. (https://doi.org/10.1016/s0303-7207(98)00117-8)

Verma A, Cohen DJ, Schwartz N, Muktipaty C, Koblinski JE, Boyan BD \& Schwartz Z 2019 24R,25-Dihydroxyvitamin D3 regulates breast cancer cells in vitro and in vivo. Biochimica et Biophysica Acta: General Subjects 1863 1498-1512. (https://doi.org/10.1016/j. bbagen.2019.05.013)

Vink-van Wijngaarden T, Pols HAP, Buurman CJ, Vandenbemd GJCM, Dorssers LCJ, Birkenhager JC \& Vanleeuwen JPTM 1994 Inhibition of breast-cancer cell-growth by combined treatment with vitamin-D-3 analogs and tamoxifen. Cancer Research 54 5711-5717.

Wahler J, So JY, Cheng LC, Maehr H, Uskokovic M \& Suh N 2015 Vitamin D compounds reduce mammosphere formation and decrease expression of putative stem cell markers in breast cancer. Journal of Steroid Biochemistry and Molecular Biology 148 148-155. (https://doi. org/10.1016/j.jsbmb.2014.10.016)

Weitsman GE, Koren R, Zuck E, Rotem C, Liberman UA \& Ravid A 2005 Vitamin D sensitizes breast cancer cells to the action of $\mathrm{H} 2 \mathrm{O} 2$ : mitochondria as a convergence point in the death pathway. Free Radical Biology and Medicine 39 266-278. (https://doi.org/10.1016/j. freeradbiomed.2005.03.018)

Welsh J 2017 Function of the vitamin D endocrine system in mammary gland and breast cancer. Molecular and Cellular Endocrinology 453 88-95. (https://doi.org/10.1016/j.mce.2017.04.026)

Welsh J 2018 Vitamin D and breast cancer: past and present. Journal of Steroid Biochemistry and Molecular Biology 177 15-20. (https://doi. org/10.1016/j.jsbmb.2017.07.025)

Williams JD, Aggarwal A, Swami S, Krishnan AV, Ji L, Albertelli MA \& Feldman BJ 2016 Tumor autonomous effects of vitamin D deficiency promote breast cancer metastasis. Endocrinology 157 1341-1347. (https://doi.org/10.1210/en.2015-2036)

Wilmanski T, Barnard A, Parikh MR, Kirshner J, Buhman K, Burgess J \& Teegarden D 2016 1alpha,25-Dihydroxyvitamin D inhibits the metastatic capability of MCF10CA1a and MDA-MB-231 cells in an in vitro model of breast to bone metastasis. Nutrition and Cancer $\mathbf{6 8}$ 1202-1209. (https://doi.org/10.1080/01635581.2016.1213868)

Wilmanski T, Buhman K, Donkin SS, Burgess JR \& Teegarden D 2017a 1alpha,25-dihydroxyvitamin D inhibits de novo fatty acid synthesis and lipid accumulation in metastatic breast cancer cells through down-regulation of pyruvate carboxylase. Journal of Nutritional Biochemistry 40 194-200. (https://doi.org/10.1016/j. jnutbio.2016.11.006)

Wilmanski T, Zhou X, Zheng W, Shinde A, Donkin SS, Wendt M, Burgess JR \& Teegarden D $2017 b$ Inhibition of pyruvate carboxylase by 1alpha,25-dihydroxyvitamin D promotes oxidative stress in early breast cancer progression. Cancer Letters 411 171-181. (https://doi. org/10.1016/j.canlet.2017.09.045)
Xu H, Liu Z, Shi H \& Wang C 2020 Prognostic role of vitamin D receptor in breast cancer: a systematic review and meta-analysis. BMC Cancer 20 1051. (https://doi.org/10.1186/s12885-020-07559-w)

Yaghjyan L, Colditz GA \& Drake B 2012 Vitamin D and mammographic breast density: a systematic review. Cancer Causes and Control 23 1-13. (https://doi.org/10.1007/s10552-011-9851-3)

Yin L, Duan JJ, Bian XW \& Yu SC 2020 Triple-negative breast cancer molecular subtyping and treatment progress. Breast Cancer Research 22 61. (https://doi.org/10.1186/s13058-020-01296-5)

Zhalehjoo N, Shakiba Y \& Panjehpour M 2017 Gene expression profiles of CYP24A1 and CYP27B1 in malignant and normal breast tissues. Molecular Medicine Reports 15 467-473. (https://doi.org/10.3892/mmr.2016.5992)

Zhang Y, Guo Q, Zhang Z, Bai N, Liu Z, Xiong M, Wei Y, Xiang R \& Tan X 2014 VDR status arbitrates the prometastatic effects of tumorassociated macrophages. Molecular Cancer Research 12 1181-1191. (https://doi.org/10.1158/1541-7786.MCR-14-0036)

Zheng W, Tayyari F, Gowda GA, Raftery D, McLamore ES, Shi J, Porterfield DM, Donkin SS, Bequette B \& Teegarden D 2013 1,25-Dihydroxyvitamin D regulation of glucose metabolism in Harvey-ras transformed MCF10A human breast epithelial cells. Journal of Steroid Biochemistry and Molecular Biology 138 81-89. (https://doi. org/10.1016/j.jsbmb.2013.03.012)

Zheng Y, Trivedi T, Lin RC, Fong-Yee C, Nolte R, Manibo J, Chen Y, Hossain M, Horas K, Dunstan C, et al. 2017 Loss of the vitamin D receptor in human breast and prostate cancers strongly induces cell apoptosis through downregulation of Wnt/beta-catenin signaling. Bone Research 5 17023. (https://doi.org/10.1038/boneres.2017.23)

Zheng W, Duan B, Zhang Q, Ouyang L, Peng W, Qian F, Wang Y \& Huang S 2018 Vitamin D-induced vitamin D receptor expression induces tamoxifen sensitivity in MCF-7 stem cells via suppression of Wnt/beta-catenin signaling. Bioscience Reports 38 BSR20180595. (https://doi.org/10.1042/BSR20180595)

Zheng W, Cao L, Ouyang L, Zhang Q, Duan B, Zhou W, Chen S, Peng W, Xie Y, Fan Q, et al. 2019 Anticancer activity of 1,25-(OH)2D3 against human breast cancer cell lines by targeting Ras/MEK/ERK pathway. OncoTargets and Therapy 12 721-732. (https://doi.org/10.2147/OTT. S190432)

Zhou X, Zheng W, Nagana Gowda GA, Raftery D, Donkin SS, Bequette B \& Teegarden D 2016 1,25-Dihydroxyvitamin D inhibits glutamine metabolism in Harvey-ras transformed MCF10A human breast epithelial cell. Journal of Steroid Biochemistry and Molecular Biology 163 147-156. (https://doi.org/10.1016/j.jsbmb.2016.04.022)

Zhou L, Chen B, Sheng L \& Turner A 2020 The effect of vitamin D supplementation on the risk of breast cancer: a trial sequential metaanalysis. Breast Cancer Research and Treatment 182 1-8. (https://doi. org/10.1007/s10549-020-05669-4)

Zinser GM \& Welsh J 2004a Accelerated mammary gland development during pregnancy and delayed postlactational involution in vitamin D3 receptor null mice. Molecular Endocrinology 18 2208-2223. (https:// doi.org/10.1210/me.2003-0469)

Zinser GM \& Welsh J 2004b Vitamin D receptor status alters mammary gland morphology and tumorigenesis in MMTV-neu mice. Carcinogenesis 25 2361-2372. (https://doi.org/10.1093/carcin/bgh271)

Zinser G, Packman K \& Welsh J 2002 Vitamin D(3) receptor ablation alters mammary gland morphogenesis. Development 129 3067-3076. (https://doi.org/10.1242/dev.129.13.3067)

Received in final form 6 December 2021

Accepted 20 December 2021

Accepted Manuscript published online 22 December 2021 https://erc.bioscientifica.com https://doi.org/10.1530/ERC-21-0182 (c) 2022 Society for Endocrinology Published by Bioscientifica Ltd. Printed in Great Britain 